\title{
STRES ZWIAZZANY Z PRACA PIELĘGNIAREK I POŁOŻNYCH ORAZ STYLE RADZENIA SOBIE ZE STRESEM
}

\section{STRESS CONNECTED WITH THE WORK OF NURSES AND MIDWIVES AND THE STYLES OF MANAGING STRESS}

\author{
Marzena Kaźmierczak, Grażyna Gebuza, Małgorzata Gierszewska, Estera Mieczkowska, \\ Agnieszka Dombrowska-Pali, Marta Kłosowska
}

Pracownia Podstaw Opieki Położniczej, Wydział Nauk o Zdrowiu, Uniwersytet Mikołaja Kopernika w Toruniu, Collegium Medicum w Bydgoszczy

DOI: https://doi.org/10.20883/ppnoz.2019.62

\begin{abstract}
STRESZCZENIE
Wstęp. Ważnym aspektem w neutralizacji napięcia emocjonalnego jest umiejętne radzenie sobie ze stresem.

Materiał i metody. Do badania włączono 174 osoby personelu pielęgniarskiego po uzyskaniu zgody Komisji Bioetycznej (KB 196/2017). Oceny radzenia sobie ze stresem dokonano według Mini-COPE.

Wyniki. Najczęstszą strategią radzenia sobie ze stresem wśród personelu pielęgniarskiego była strategia „aktywne radzenie sobie”. Nie wykazano różnicy istotnej statystycznie między stylami radzenia sobie w grupie pielęgniarek i położnych $(p>0,05)$. Pracownicy medyczni w wieku powyżej 50 lat istotnie częściej stosowali strategię „obwinianie siebie” ( $p=0,0383)$. Staż pracy (16-20 lat) istotnie częściej warunkował wybór strategii „poszukiwanie wsparcia emocjonalnego" $(p<0,05)$ i „obwinianie siebie” ( $p<0,01)$. Satysfakcja z pracy zawodowej istotnie częściej dotyczyła wyboru strategii „pozytywne przewartościowanie” $i$ „poszukiwanie wsparcia instrumentalnego” $(p<0,05)$. Brak współpracy w zespole terapeutycznym istotnie częściej warunkował wybór strategii „zajmowanie się czymś innym” ( $p<0,01)$. Personel pielęgniarski z Brodnicy istotnie częściej stosował strategię „pozytywne przewartościowanie” $(p<0,01)$. Pracownicy ochrony zdrowia z Rypina istotnie częściej wybierali strategię „poczucie humoru” $(p<0,05)$. Pielęgniarki i położne z Bydgoszczy istotnie częściej skłaniali się do wyboru strategii „poszukiwanie wsparcia emocjonalnego” $(p<0,05)$.

Wnioski. Wykonywanie zawodu pielęgniarki i położnej w istotny sposób generuje ryzyko wysokiej ekspozycji na występowanie stresu. Pomimo licznych czynników, które wywołują wzmożone napięcie emocjonalne wśród pracowników ochrony zdrowia, badana próba stosowała aktywne strategie neutralizacji stresu, co w znaczny sposób przyczynia się do zachowania zdrowia psychosomatycznego.
\end{abstract}

Słowa kluczowe: położna, pielęgniarka, praca, stres, radzenie sobie ze stresem, Inwentarz do Pomiaru Radzenia Sobie ze Stresem (Mini-COPE).

\section{ABSTRACT}

Introduction. Coping with stress in the right manner constitutes an important aspect of neutralising emotional tension.

Material and methods. After receiving the approval of Bioethics Committee (KB 196/2017), 174 individuals from nursing staff were included into thestudy. The assessment of coping with stress was conducted with the use of Mini-COPE.

Results. The strategy of "active coping" was the most frequent manner of handling stress amongst nursing staff. No statistically significant difference between the styles of coping with stress amongst nurses and midwives was found $(p>0.05)$. Health professionals over 50 years old used the strategy of "blaming themselves" significantly more frequently $(p=0.0383)$. Professional experience $(16-20$ years) conditioned choosing the strategy of "looking for emotional support" ( $p<0.05)$ and "blaming oneself" ( $p<0.01)$ significantly more frequently.Job satisfaction concerned choosing the strategy of "positive revaluation" and "looking for instrumental support" ( $p<0.05)$. Lack of cooperation within a therapeutic team conditioned choosing the strategy of "dealing with something else" significantly more frequently $(p<0.01)$. The nursing staff from Brodnica used the strategy of "positive revaluation" significantly more often. Health professionals from Rypin chose the strategy of "sense of humour" significantly more frequently $(p<0.05)$. Nurses and midwives from Bydgoszcz would choose the strategy of "looking for emotional support" significantly more often.

Conclusions. Performing the occupation of nurse and midwife generates a considerable risk of exposure to stress.In spite of numerous factors evoking emotional tension amongst health professionals the study group used active strategies of neutralising stress. This, in turn, significantly contributes to maintaining mental health.

Keywords: midwife, nurse, work, stress, coping with stress, Inventory for Measuring Coping with Stress (Mini-COPE).

\section{Wstęp}

Aktywność zawodowa pielęgniarki i położnej to profesje, w których potrzebne są osobiste uwarunkowania. Są to zawody charakteryzujące się koniecznością posiadania obszernej wiedzy teoretycznej i praktycznej. Aktualnie pielęgniarka i położna, to specjalistki posiadające profe- sjonalną wiedzę, nie tylko z zakresu nauk medycznych, ale również z dziedzin pokrewnych (socjologii, pedagogiki, psychologii), które są samodzielnymi pracownikami odpowiedzialnymi za realizację zadań zawodowych. Pełnią one różne funkcje zawodowe: opiekuńcze, wychowawcze, 
promujące zdrowie, profilaktyczne, terapeutyczne, a także kształcące, badawcze i związane z zarządzaniem. Praca w szpitalu odbywa się w specyficznych, niekorzystnych dla zdrowia warunkach, dlatego wymaga od personelu pielęgniarskiego dobrej kondycji fizycznej i psychicznej. Struktura pracy organizacyjnej pielęgniarek i położnych jest złożona i specyficzna, gdyż ma charakter wielozadaniowy [1]. Pielęgniarstwo, jako zawód usług społecznych, jest narażone na działanie różnych czynników stresogennych związanych z ochroną i ratowaniem życia [2]. Pielęgniarki i położne, w aktualnej sytuacji systemu ochrony zdrowia, to jedna z najbardziej narażonych na stres grup zawodowych. Podłożem stresu może być bezpośredni kontakt z pacjentem oraz jego bliskimi, współdziałanie z innymi członkami zespołu terapeutycznego oraz praca ze szkodliwymi czynnikami, negatywnie wpływającymi na zdrowie człowieka [3]. Wśród źródeł stresu nie można pominąć takich czynników, jak: zmianowość pracy, zakłócająca naturalny rytm biologiczny organizmu, praca nierytmiczna, powodująca okresowo duże przeciążenia, brak satysfakcjonującego wynagrodzenia czy brak uznania w opinii przełożonych. Wymieniając źródła stresu w pracy pielęgniarek i położnych, nie sposób podkreślić szerokiego zakresu odpowiedzialności związanej z wykonywanymi obowiązkami zawodowymi, presji bycia niezawodnym i dyspozycyjnym oraz oczekiwań ze strony pacjentów i ich rodzin [4]. Zwiększający się stres powoduje zróżnicowane, specyficzne i niespecyficzne zmiany $w$ organizmie człowieka, zachodzące w procesach, zarówno fizjologicznych, jak i psychologicznych.

Do najczęściej występujących zaburzeń, których źródłem może być nadmierny stres należą: zaburzenia sercowo-naczyniowe, choroby skórne, nieprawidłowości w obrębie przewodu pokarmowego oraz depresja [5]. Zapobieganie negatywnym skutkom stresu i radzenie sobie z nimi to warunki utrzymania wysokiej efektywności i podtrzymania satysfakcji z wykonywanej pracy. Radzenie sobie ze stresem spełnia dwie funkcje: instrumentalną (zadaniową) - zorientowaną na problem, czyli na poprawę relacji podmiotu z otoczeniem, oraz funkcję samoregulacji emocji - polegającą zwykle na obniżaniu przykrego napięcia i łagodzeniu innych negatywnych stanów emocjonalnych [6]. Naturalną reakcją na wystąpienie stresu jest dążenie do ograniczenia jego działania przez "mechanizm copingu". Zdaniem amerykańskiego psychologa Richarda S. Lazarusa radzenie sobie ze stresem to „(...) stale zmieniające się poznawcze i behawioralne wysiłki, mające na celu opanowanie określonych zewnętrznych i wewnętrznych wymagań, ocenianych przez osobę jako obciążające lub przekraczające jej zasoby"[7].
Głównym celem badania była ocena najczęściej stosowanych strategii radzenia sobie ze stresem wśród aktywnego zawodowo personelu pielęgniarskiego oraz ustalenie zmiennych, które różnicują poszczególne strategie.

\section{Materiał i metody}

Do badania włączono 174 osoby personelu pielęgniarskiego po uzyskaniu zgody Komisji Bioetycznej Uniwersytetu Mikołaja Kopernika w Toruniu (nr KB 196/2017) oraz dyrekcji placówek leczniczych: Samodzielny Publiczny Zakład Opieki Zdrowotnej w Rypinie, Samodzielny Publiczny Zakład Opieki Zdrowotnej w Brodnicy, Szpital Powiatowy w Nowym Mieście Lubawskim oraz Centrum Onkologii w Bydgoszczy.

Do badania włączono aktywny zawodowo personel pielęgniarski, różnych specjalności, placówek medycznych i oddziałów (m.in. O. Chirurgii Ogólnej i Urazowej, O. Dziecięcego z Neonatologią, O. Chorób Wewnętrznych, O. Położniczo-Ginekologicznego, O. Urologii, O. Pediatrii, O. Klinicznego Ginekologii Onkologicznej, O. Klinicznego Chirurgii Onkologicznej, O. Klinicznego Nowotworów Piersi i Chirurgii Rekonstrukcyjnej, O. Chemioterapii oraz O. Klinicznego Radioterapii, a także Izby Przyjęć i OIOM). Pielęgniarki/arze i położne z Bydgoszczy oraz Rypina stanowili odpowiednio po $29,88 \%$ badanych, Brodnicy $-16,09 \%$, a Nowego Miasta Lubawskiego-24,14\%. Pielęgniarki/pielęgniarze stanowili $76,44 \%$ badanej próby ( $n=133$, $w$ tym 3 mężczyzn), położnych było $23,56 \%(n=41)$. Szczegółowe dane socjodemograficzne oraz zawodowe badane próby przedstawiono $\mathrm{w}$ tabeli 1 .

Tabela 1. Dane socjodemograficzne i zawodowe badanej próby

\begin{tabular}{|c|c|c|c|}
\hline Zmienne & Odpowiedzi & $\mathrm{N}$ & $\%$ \\
\hline \multirow{2}{*}{ Płeć } & Kobieta & 171 & 98,28 \\
\hline & Mężczyzna & 3 & 1,72 \\
\hline \multirow[t]{3}{*}{ Ogółem } & & 174 & 100 \\
\hline & Liceum medyczne & 46 & 26,44 \\
\hline & $\begin{array}{l}\text { Medyczne studium } \\
\text { zawodowe }\end{array}$ & 18 & 10,34 \\
\hline \multirow[t]{3}{*}{ Wykształcenie } & $\begin{array}{c}\text { Licencjat pielęgniarstwa/ } \\
\text { położnictwa }\end{array}$ & 52 & 29,88 \\
\hline & $\begin{array}{c}\text { Magister pielęgniarstwa/ } \\
\text { położnictwa }\end{array}$ & 57 & 32,76 \\
\hline & Inne & 1 & 0,57 \\
\hline Ogółem & & 174 & 100 \\
\hline
\end{tabular}




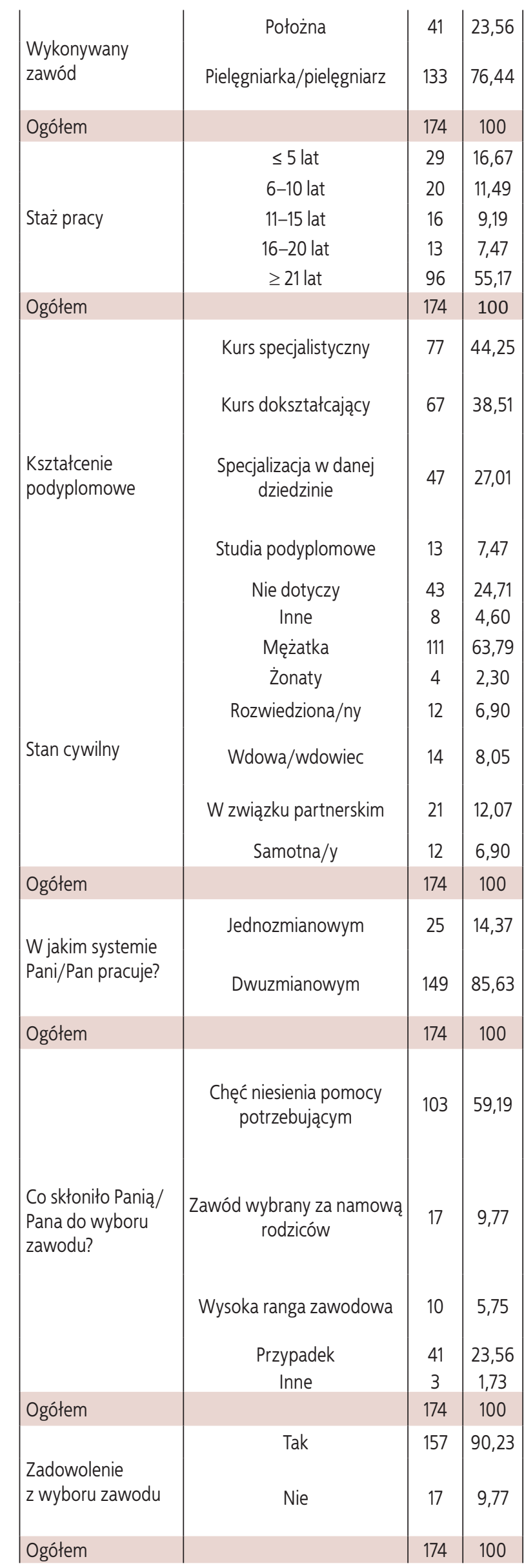

Badanie przeprowadzono metodą sondażu diagnostycznego z wykorzystaniem narzędzia standaryzowanego, jakim jest Inwentarz do Pomiaru Radzenia Sobie ze Stresem (Mini-COPE) oraz kwestionariusza ankiety własnego autorstwa. Kwestionariusz ankiety składał się z 25 pytań. Pytania o płeć, wiek, wykształcenie i stan cywilny zawarto w metryczce. Kolejne pytania dotyczyły danych zawodowych, takich jak: staż pracy, kursy kwalifikacyjne oraz system pracy (jednozmianowy, dwuzmianowy). Respondentów pytano również o wybór profesji oraz zadowolenia z dokonanego wyboru zawodu. Dalsza część kwestionariusza dotyczyła sytuacji stresowych w miejscu pracy, na jakie w czasie wykonywania obowiązków narażone są pielęgniarki i położne, częstości występowania zdarzeń wywołujących stres, przykładowych sytuacji wywołujących napięcie oraz symptomów psychicznych i fizycznych. Pozostałe pytania dotyczyły metod redukcji napięcia emocjonalnego, rodzajów wsparcia emocjonalnego oraz strategii radzenia sobie z czynnikami stresowymi.

Inwentarz do Pomiaru Radzenia Sobie ze Stresem (MiniCOPE) autorstwa Ch. S. Carver'a w adaptacji Z. Juczyńskiego i N. Ogińskiej-Bulik jest narzędziem używanym do oceny radzenia sobie w sytuacjach stresowych. W swoim składzie zawiera 28 twierdzeń, wchodzących w budowę 14 stylów radzenia sobie w sytuacjach stresowych (po 2 założenia $w$ każdym stylu radzenia sobie). Odpowiedzi mieszczą się w przedziale od 0 do 3, z czego 0 - oznacza: prawie nigdy tak nie postępuję, 1: rzadko tak postępuję, 2: często tak postępuję, 3: prawie zawsze tak postępuję. Poszczególne strategie dzielą się na następujące czynniki: „aktywne radzenie sobie” (aktywne radzenie sobie, planowanie, pozytywne przewartościowanie), „bezradność" (zażywanie substancji psychoaktywnych, zaprzestanie działań i obwinianie siebie), „poszukiwanie wsparcia" (poszukiwanie wsparcia emocjonalnego, poszukiwanie wsparcia instrumentalnego), „zachowania unikowe” (zajmowanie się czymś innym, zaprzeczanie, wyładowania), pozostałe style: "zwrot ku religii”, „akceptacja” oraz „poczucie humoru" tworzą odrębne elementy [8].

Analizę materiału badawczego przeprowadzono za pomocą pakietu statystycznego firmy PQStat wersja 1.6.4.122. Porównania wyników strategii radzenia sobie ze stresem na podstawie skali Mini-COPE przeprowadzono testem Friedmana oraz testem post-hoc Dunna z poprawką Bonferroniego. Związki między strategiami radzenia sobie ze stresem, a wiekiem analizowano, szacując współczynniki korelacj monotonicznej Spearmana. Wyniki strategii radzenia sobie ze stresem w porównywanych grupach analizowano testem U Manna-Whitneya (gdy $k=2$ ), testem Kruskala-Wallisa oraz post-hoc Dunna z poprawką Bonferroniego (gdy k > 2). Za istotne przyjęto prawdopodobieństwo testowe na poziomie 
$p<0,05$, a za wysoce istotne przyjęto prawdopodobieństwo testowe na poziomie $p<0,01$.

\section{Wyniki}

Średnia wieku badanej próby wynosiła 43,97 lat z SD = 10,66. Mediana wieku to 47 lat, a zakres wieku wynosił od 23 do 63 lat. Połowa ankietowanych była w wieku od 36 do 52 lat. Prawie wszyscy respondenci potwierdzili występowanie sytuacji stresowych w miejscu pracy $(96,55 \%)$ Ponad połowa badanych osób $(64,94 \%)$ często doświadczała występowania wzmożonego napięcia związanego z pracą. Najczęstszymi formami rozładowania negatywnych emocji związanych z pracą zawodową było: czytanie książek lub czasopism (44,83\%), oglądanie telewizji $(43,10 \%)$, spacery $(39,08 \%)$, spotkania towarzyskie $(38,51 \%)$, jazda na rowerze $(34,48 \%)$ oraz uprawa ogródka (34,48\%). Sytuacje, które wywołują wzmożony stres u respondentów, to najczęściej: duża liczba zadań przypadająca na jednego pracownika (79,31\%), niedostateczna liczba pracowników (70,69\%), zbyt niskie wynagrodzenie $(53,45 \%)$, śmierć pacjenta $(43,10 \%)$, ale także brak wsparcia ze strony przełożonych (21,84\%), mobbing $(17,24 \%)$ i brak współpracy między poszczególnymi członkami zespołu terapeutycznego stwierdziło (25,29\%).

208 Najczęściej odczuwane objawy stresu dotyczące sfery psychicznej zgłaszane przez pracowników medycznych, to: nerwowość $(56,90 \%)$, rozdrażnienie $(51,15 \%)$, zaburzenia związane ze snem (36,78\%), obniżony nastrój $(35,63 \%)$ oraz uczucie gniewu (33,91\%). Najczęściej odczuwane symptomy stresu dotyczące sfery somatycznej zgłaszane przez personel pielęgniarski to: bóle okolic kręgosłupa (64,37\%), długo utrzymujące się nadmierne napięcie emocjonalne (40,23\%), wzmożona potliwość $(29,88 \%)$ oraz bóle i zawroty głowy $(25,29 \%)$. Większość respondentów (77,59\%) deklarowała, że jest zadowolona z osiągnięć zawodowych. Problemy rodzinne związane z pracą zawodową zgłosiło 16,67\% badanych. Pracownicy opieki medycznej najczęściej otrzymują wsparcie emocjonalne od koleżanek z pracy lub innych współpracowników $(48,85 \%)$ oraz od partnerów życiowych (44,83\%). Z agresją słowną w miejscu pracy miało kontakt 75,29\% ankietowanych. Prawie połowa personelu pielęgniarskiego $(47,70 \%)$ spotkała się z agresją słowną od rodziny pacjentów, od samych pacjentów agresji doświadczyło 43,10\% badanych, a od lekarzy - 31,61\%. Korzystanie z używek w celu złagodzenia stresu deklarowało 28,90\% osób. Najczęstszą używką stosowaną przez personel pielęgniarski były papierosy (18,39\%). Większość ankietowanych $(74,72 \%)$ przyznała, że praca wiąże się występowaniem obciążenia emocjonalnego. Odpowiedzi respondentów na temat radzenia sobie ze stresem były następujące: „skupiam się na rozwiązaniu problemu” (39,08\%) , „zachowuję dystans do problemu” (27,59\%), „szukam wsparcia emocjonalnego od innych osób” (21,84\%) oraz „odczuwam złość do osób, które zapoczątkowały problem" (11,49\%).

W celu odpowiedzi na pytanie, jakie najczęściej strategie radzenia sobie ze stresem stosowali pracownicy medyczni, dokonano analizy na podstawie Inwentarza do Pomiaru Radzenia Sobie ze Stresem (Mini-COPE). Średnia arytmetyczna dotycząca „aktywnego radzenia sobie ze stresem" wynosiła 2,20. Wysoką średnią arytmetyczną obrazuje również sposób radzenia sobie ze stresem, jakim jest „planowanie" (2,16). Najniższą średnią arytmetyczną przedstawia strategia „bezradność” - „zażywanie substancji psychoaktywnych" $(0,33)$. Poszczególne strategie radzenia sobie ze stresem różnią się od siebie wysoce istotnie $(p<0,0001)$, należy więc wnioskować, że pielęgniarki/arze i położne są grupą zawodową stosującą strategię "aktywne radzenie sobie”. Szczegółowe dane zawarto w tabeli 2. Nie stwierdzono różnicy istotnej statystycznie między strategiami radzenia sobie ze stresem w grupie zawodowej pielęgniarek i położnych $(p>0,05)$. Dane z obserwacji przedstawiono $w$ tabeli 3

W pracy ustalono, że istnieją zmienne niezależne, które mają związek z wyborem strategii radzenia sobie ze stresem w grupie pielęgniarek i położnych. W wyniku analizy statystycznej wykazano, że wraz ze wzrostem wieku pracownicy ochrony zdrowia stosowali strategię „obwinianie siebie" ( $p=0,03)$. W przypadku pozostałych strategii nie stwierdzono różnicy istotnej statystycznie $(p>0,05)$. Dane z obserwacji zawarto w tabeli 4

Ukończenie studiów podyplomowych wśród pielęgniarekipołożnych istotniewarunkowało strategię „pozytywne przewartościowanie” oraz „zwrot ku religii” $(p<0,05)$. Pracownicy ochrony zdrowia, którzy ukończyli liceum medyczne istotnie częściej stosowali strategię „bezradności” - „zaprzestanie działań" $(p<0,05)$. Dane z obserwacji zawarto w tabeli 5.

Wraz ze wzrostem stażu pracy (16-20 lat) pracownicy ochrony zdrowia istotnie częściej stosowali strategię „poszukiwanie wsparcia emocjonalnego" $(p<0,05)$ oraz "obwinianie siebie" $(p<0,01)$ - tabela 6. Poziom satysfak cji z pracy zawodowej badanej próby istotnie warunkował strategie: „pozytywne przewartościowanie” ( $p<0,05)$, „zwrot ku religii” ( $p<0,05)$, „poszukiwanie wsparcia emocjonalnego" ( $p<0,05)$ oraz "poszukiwanie wsparcia instrumentalnego" ( $p<0,05)$. Dane z obserwacji zawarto $w$ tabeli 7. Brak współpracy między członkami zespołu terapeutycznego w badanej próbie istotnie częściej warunkował wybór strategii „aktywne radzenia sobie” 
Tabela 2. Statystyki opisowe skali Mini-COPE w badanej próbie

\begin{tabular}{|c|c|c|c|c|c|c|c|}
\hline $\begin{array}{l}\text { Strategie radzenia sobie ze stresem wg } \\
\text { Mini-COPE }\end{array}$ & 离 & 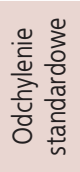 & $\dot{\mathscr{L}}$ & 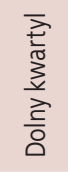 & 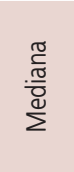 & 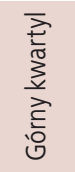 & $\sum^{\frac{x}{\pi}}$ \\
\hline Aktywne radzenie sobie & 2,20 & 0,63 & 0,00 & 2,00 & 2,00 & 2,50 & 3,00 \\
\hline Planowanie & 2,16 & 0,65 & 0,00 & 2,00 & 2,00 & 2,50 & 3,00 \\
\hline Pozytywne przewartościowanie & 1,80 & 0,69 & 0,00 & 1,50 & 2,00 & 2,50 & 3,00 \\
\hline Akceptacja & 1,80 & 0,71 & 0,00 & 1,50 & 2,00 & 2,50 & 3,00 \\
\hline Poczucie humoru & 0,67 & 0,65 & 0,00 & 0,00 & 0,50 & 1,00 & 3,00 \\
\hline Zwrot ku religii & 1,31 & 0,99 & 0,00 & 0,50 & 1,00 & 2,00 & 3,00 \\
\hline Poszukiwanie wsparcia emocjonalnego & 1,90 & 0,66 & 0,00 & 1,50 & 2,00 & 2,50 & 3,00 \\
\hline Poszukiwanie wsparcia instrumentalnego & 1,86 & 0,67 & 0,00 & 1,50 & 2,00 & 2,00 & 3,00 \\
\hline Zajmowanie się czymś innym & 1,85 & 0,71 & 0,00 & 1,50 & 2,00 & 2,50 & 3,00 \\
\hline Zaprzeczanie & 0,85 & 0,73 & 0,00 & 0,50 & 0,50 & 1,50 & 3,00 \\
\hline Wyładowanie & 1,26 & 0,71 & 0,00 & 0,50 & 1,50 & 1,50 & 3,00 \\
\hline Zażywanie substancji psychoaktywnych & 0,33 & 0,61 & 0,00 & 0,00 & 0,00 & 0,50 & 3,00 \\
\hline Zaprzestanie działań & 0,83 & 0,73 & 0,00 & 0,00 & 0,75 & 1,50 & 3,00 \\
\hline Obwinianie siebie & 0,97 & 0,75 & 0,00 & 0,50 & 1,00 & 1,50 & 3,00 \\
\hline
\end{tabular}

Tabela 3. Strategie radzenia sobie ze stresem wg Mini-COPE ze względu na wykonywany zawód

\begin{tabular}{|c|c|c|c|c|c|c|c|c|c|}
\hline $\begin{array}{l}\text { Strategie radzenia sobie ze stresem } \\
\text { wg Mini-COPE }\end{array}$ & 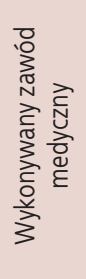 & 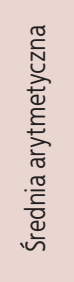 & 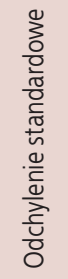 & 志 & 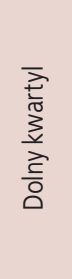 & 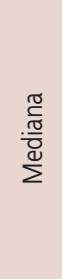 & 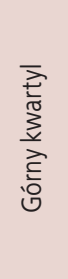 & 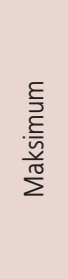 & 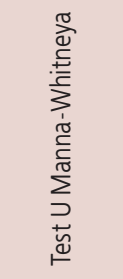 \\
\hline \multirow{2}{*}{ Aktywne radzenie sobie } & 1 & 2,21 & 0,65 & 0,00 & 2,00 & 2,00 & 3,00 & 3,00 & $Z=0,4965$ \\
\hline & 2 & 2,17 & 0,57 & 1,00 & 2,00 & 2,00 & 2,50 & 3,00 & $p=0,6196$ \\
\hline \multirow{2}{*}{ Planowanie } & 1 & 2,15 & 0,69 & 0,00 & 1,50 & 2,00 & 3,00 & 3,00 & $Z=0,1564$ \\
\hline & 2 & 2,18 & 0,52 & 1,00 & 2,00 & 2,00 & 2,50 & 3,00 & $p=0,8758$ \\
\hline \multirow{2}{*}{ Pozytywne przewartościowanie } & 1 & 1,78 & 0,71 & 0,00 & 1,00 & 2,00 & 2,00 & 3,00 & $Z=0,8279$ \\
\hline & 2 & 1,87 & 0,65 & 0,50 & 1,50 & 2,00 & 2,50 & 3,00 & $p=0,4077$ \\
\hline \multirow{2}{*}{ Akceptacja } & 1 & 1,82 & 0,72 & 0,00 & 1,50 & 2,00 & 2,50 & 3,00 & $Z=0,5303$ \\
\hline & 2 & 1,74 & 0,71 & 0,00 & 1,50 & 2,00 & 2,00 & 3,00 & $p=0,5959$ \\
\hline \multirow[b]{2}{*}{ Poczucie humoru } & 1 & 0,70 & 0,67 & 0,00 & 0,00 & 0,50 & 1,00 & 3,00 & $Z=1,0102$ \\
\hline & 2 & 0,57 & 0,60 & 0,00 & 0,00 & 0,50 & 1,00 & 2,00 & $p=0,3124$ \\
\hline \multirow{2}{*}{ Zwrot ku religii } & 1 & 1,29 & 0,99 & 0,00 & 0,50 & 1,00 & 2,00 & 3,00 & $Z=0,5254$ \\
\hline & 2 & 1,38 & 1,00 & 0,00 & 0,50 & 1,50 & 2,00 & 3,00 & $p=0,5993$ \\
\hline \multirow[b]{2}{*}{ Poszukiwanie wsparcia emocjonalnego } & 1 & 1,86 & 0,70 & 0,00 & 1,50 & 2,00 & 2,50 & 3,00 & $Z=1,4128$ \\
\hline & 2 & 2,05 & 0,52 & 1,00 & 2,00 & 2,00 & 2,50 & 3,00 & $p=0,1577$ \\
\hline \multirow[b]{2}{*}{ Poszukiwanie wsparcia instrumentalnego } & 1 & 1,85 & 0,69 & 0,00 & 1,50 & 2,00 & 2,50 & 3,00 & $Z=0,5741$ \\
\hline & 2 & 1,91 & 0,58 & 0,50 & 1,50 & 2,00 & 2,00 & 3,00 & $p=0,5659$ \\
\hline \multirow{2}{*}{ Zajmowanie się czymś innym } & 1 & 1,84 & 0,74 & 0,00 & 1,50 & 2,00 & 2,50 & 3,00 & $Z=0,0963$ \\
\hline & 2 & 1,87 & 0,60 & 0,50 & 1,50 & 2,00 & 2,50 & 3,00 & $p=0,9233$ \\
\hline \multirow{2}{*}{ Zaprzeczanie } & 1 & 0,85 & 0,72 & 0,00 & 0,00 & 1,00 & 1,50 & 3,00 & $Z=0,0527$ \\
\hline & 2 & 0,85 & 0,75 & 0,00 & 0,50 & 0,50 & 1,50 & 2,50 & $p=0,9580$ \\
\hline \multirow{2}{*}{ Wyładowanie } & 1 & 1,20 & 0,74 & 0,00 & 0,50 & 1,50 & 1,50 & 3,00 & $Z=1,8419$ \\
\hline & 2 & 1,44 & 0,59 & 0,00 & 1,00 & 1,50 & 2,00 & 2,50 & $p=0,0655$ \\
\hline \multirow{2}{*}{ Zażywanie substancji psychoaktywnych } & 1 & 0,30 & 0,55 & 0,00 & 0,00 & 0,00 & 0,50 & 3,00 & $\mathrm{Z}=0,5332$ \\
\hline & 2 & 0,43 & 0,75 & 0,00 & 0,00 & 0,00 & 1,00 & 2,50 & $p=0,5939$ \\
\hline \multirow{2}{*}{ Zaprzestanie działań } & 1 & 0,81 & 0,72 & 0,00 & 0,00 & 0,50 & 1,50 & 3,00 & $Z=0,6764$ \\
\hline & 2 & 0,90 & 0,75 & 0,00 & 0,50 & 1,00 & 1,50 & 3,00 & $p=0,4988$ \\
\hline \multirow{2}{*}{ Obwinianie siebie } & 1 & 0,95 & 0,75 & 0,00 & 0,50 & 1,00 & 1,50 & 3,00 & $Z=0,4371$ \\
\hline & 2 & 1,04 & 0,79 & 0,00 & 0,50 & 1,00 & 1,50 & 3,00 & $p=0,6620$ \\
\hline
\end{tabular}


Tabela 4. Strategie radzenia sobie ze stresem wg Mini-COPE ze względu na wiek

\begin{tabular}{|l|c|c|}
\multicolumn{1}{|c|}{ Strategie radzenia sobie ze stresem wg Mini-COPE } & $r$ & $p$ \\
\hline Aktywne radzenie sobie & 0,0477 & 0,5315 \\
\hline Planowanie & 0,0141 & 0,8534 \\
\hline Pozytywne przewartościowanie & 0,0156 & 0,8381 \\
\hline Akceptacja & 0,0108 & 0,8880 \\
\hline Poczucie humoru & $-0,0680$ & 0,3724 \\
\hline Zwrot ku religii & 0,1050 & 0,1680 \\
\hline Poszukiwanie wsparcia emocjonalnego & $-0,1816$ & 0,0164 \\
\hline Poszukiwanie wsparcia instrumentalnego & $-0,0449$ & 0,5561 \\
\hline Zajmowanie się czymś innym & 0,0020 & 0,9789 \\
\hline Zaprzeczanie & 0,0465 & 0,5426 \\
Wyładowanie & $-0,1038$ & 0,1729 \\
\hline Zażywanie substancji psychoaktywnych & $-0,0827$ & 0,2778 \\
\hline Zaprzestanie działań & 0,0159 & 0,8346 \\
\hline Obwinianie siebie & $-0,1572$ & 0,0383 \\
\hline
\end{tabular}

Tabela 5. Strategie radzenia sobie ze stresem wg Mini-COPE ze względu na wykształcenie

\begin{tabular}{|c|c|c|c|c|c|c|c|c|c|c|c|c|c|}
\hline \multirow[b]{2}{*}{$\begin{array}{c}\text { Strategie radzenia sobie ze } \\
\text { stresem } \\
\text { wg Mini-COPE }\end{array}$} & \multirow{2}{*}{ 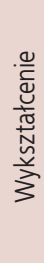 } & \multirow{2}{*}{ 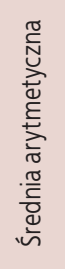 } & \multirow{2}{*}{ 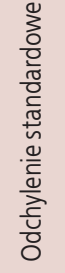 } & \multirow[b]{2}{*}{ 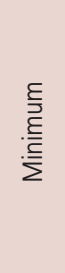 } & \multirow{2}{*}{ 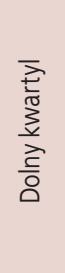 } & \multirow[b]{2}{*}{ 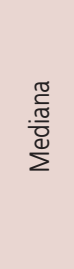 } & \multirow{2}{*}{ 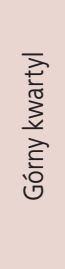 } & \multirow[b]{2}{*}{ 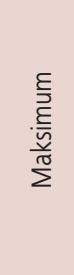 } & \multirow{2}{*}{ 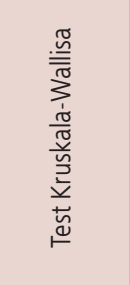 } & \multicolumn{4}{|c|}{ Test Dunna-Bonferroniego } \\
\hline & & & & & & & & & & $\dot{*}$ & * & $\stackrel{m}{*}$ & $*^{*}$ \\
\hline \multirow{4}{*}{ Aktywne radzenie sobie } & 1 & 2,03 & 0,71 & 0,00 & 1,63 & 2,00 & 2,50 & 3,00 & \multirow{4}{*}{$\begin{array}{l}H=7,1403 \\
p=0,0676\end{array}$} & \multirow{4}{*}{0,8} & 0,8547 & 1 & 0,1108 \\
\hline & 2 & 2,33 & 0,49 & 1,50 & 2,00 & 2,50 & 2,50 & 3,00 & & & & 1 & 1 \\
\hline & 3 & 2,13 & 0,58 & 1,00 & 2,00 & 2,00 & 2,50 & 3,00 & & & 1 & & 0,3161 \\
\hline & 4 & 2,35 & 0,61 & 0,50 & 2,00 & 2,50 & 3,00 & 3,00 & & & 1 & 0,3161 & \\
\hline \multirow{4}{*}{ Planowanie } & 1 & 2,03 & 0,74 & 0,00 & 1,50 & 2,00 & 2,50 & 3,00 & \multirow{4}{*}{$\begin{array}{c}H=2,175 \\
p=0,5369\end{array}$} & & 1 & 1 & 1 \\
\hline & 2 & 2,11 & 0,83 & 0,00 & 2,00 & 2,00 & 2,88 & 3,00 & & 1 & & 1 & 1 \\
\hline & 3 & 2,21 & 0,61 & 1,00 & 2,00 & 2,00 & 2,63 & 3,00 & & 1 & 1 & & 1 \\
\hline & 4 & 2,23 & 0,54 & 1,00 & 2,00 & 2,00 & 2,50 & 3,00 & & 1 & 1 & 1 & \\
\hline \multirow{4}{*}{$\begin{array}{l}\text { Pozytywne } \\
\text { przewartościowanie }\end{array}$} & 1 & 1,75 & 0,66 & 0,50 & 1,13 & 2,00 & 2,00 & 3,00 & \multirow{4}{*}{$\begin{array}{l}H=9,5104 \\
p=0,0232\end{array}$} & & 0,0796 & 1 & 1 \\
\hline & 2 & 2,14 & 0,84 & 0,00 & 2,00 & 2,50 & 2,50 & 3,00 & & 0,0796 & & 0,2905 & 0,0165 \\
\hline & 3 & 1,86 & 0,68 & 0,50 & 1,50 & 2,00 & 2,13 & 3,00 & & 1 & 0,2905 & & 0,9554 \\
\hline & 4 & 1,66 & 0,64 & 0,00 & 1,00 & 2,00 & 2,00 & 3,00 & & 1 & 0,0165 & 0,9554 & \\
\hline \multirow{4}{*}{ Akceptacja } & 1 & 1,85 & 0,75 & 0,00 & 1,50 & 2,00 & 2,50 & 3,00 & \multirow{4}{*}{$\begin{array}{l}H=1,548 \\
p=0,6712\end{array}$} & & 1 & 1 & 1 \\
\hline & 2 & 1,86 & 0,84 & 0,00 & 1,25 & 2,00 & 2,50 & 3,00 & & 1 & & 1 & 1 \\
\hline & 3 & 1,81 & 0,70 & 0,00 & 1,50 & 2,00 & 2,50 & 3,00 & & 1 & 1 & & 1 \\
\hline & 4 & 1,73 & 0,67 & 0,00 & 1,50 & 1,50 & 2,00 & 3,00 & & 1 & 1 & 1 & \\
\hline \multirow{4}{*}{ Poczucie humoru } & 1 & 0,85 & 0,78 & 0,00 & 0,00 & 0,75 & 1,50 & 3,00 & \multirow{4}{*}{$\begin{array}{l}H=4,1097 \\
p=0,2499\end{array}$} & & 1 & 0,3211 & 1 \\
\hline & 2 & 0,56 & 0,54 & 0,00 & 0,00 & 0,50 & 0,88 & 1,50 & & 1 & & 1 & 1 \\
\hline & 3 & 0,58 & 0,67 & 0,00 & 0,00 & 0,50 & 1,00 & 2,50 & & 0,3211 & 1 & & 1 \\
\hline & 4 & 0,65 & 0,54 & 0,00 & 0,00 & 0,50 & 1,00 & 2,00 & & 1 & 1 & 1 & \\
\hline \multirow{4}{*}{ Zwrot ku religii } & 1 & 1,34 & 0,99 & 0,00 & 0,50 & 1,00 & 2,00 & 3,00 & \multirow{4}{*}{$\begin{array}{l}H=9,4033 \\
p=0,0244\end{array}$} & \multirow{4}{*}{$\begin{array}{c}0,1475 \\
1 \\
1\end{array}$} & 0,1475 & 1 & 1 \\
\hline & 2 & 1,97 & 0,93 & 0,00 & 1,50 & 2,00 & 3,00 & 3,00 & & & & 0,0388 & 0,0182 \\
\hline & 3 & 1,22 & 0,96 & 0,00 & 0,50 & 1,00 & 2,00 & 3,00 & & & 0,0388 & & 1 \\
\hline & 4 & 1,15 & 0,99 & 0,00 & 0,00 & 1,00 & 2,00 & 3,00 & & & 0,0182 & 1 & \\
\hline & 1 & 1,79 & 0,67 & 0,50 & 1,50 & 2,00 & 2,00 & 3,00 & & & 1 & 0,7349 & 1 \\
\hline Poszukiwanie wsparcia & 2 & 1,94 & 0,76 & 0,00 & 1,63 & 2,00 & 2,38 & 3,00 & $\mathrm{H}=2,784$ & 1 & & 1 & 1 \\
\hline emocjonalnego & 3 & 1,97 & 0,68 & 0,00 & 1,50 & 2,00 & 2,50 & 3,00 & $p=0,4261$ & 0,7349 & 1 & & 1 \\
\hline & 4 & 1,93 & 0,61 & 0,50 & 1,50 & 2,00 & 2,50 & 3,00 & & 1 & 1 & 1 & \\
\hline & 1 & 1,87 & 0,65 & 0,00 & 1,50 & 2,00 & 2,38 & 3,00 & & & 1 & 1 & 1 \\
\hline Poszukiwanie wsparcia & 2 & 1,92 & 0,73 & 0,50 & 1,50 & 2,00 & 2,50 & 3,00 & $H=0,1236$ & 1 & & 1 & 1 \\
\hline instrumentalnego & 3 & 1,88 & 0,73 & 0,00 & 1,50 & 2,00 & 2,50 & 3,00 & $p=0,9889$ & 1 & 1 & & 1 \\
\hline & 4 & 1,85 & 0,60 & 0,50 & 1,50 & 2,00 & 2,00 & 3,00 & & 1 & 1 & 1 & \\
\hline
\end{tabular}




\begin{tabular}{|c|c|c|c|c|c|c|c|c|c|c|c|c|c|}
\hline \multirow{4}{*}{ Zajmowanie się czymś innym } & 1 & 1,91 & 0,78 & 0,50 & 1,50 & 2,00 & 2,50 & 3,00 & \multirow{4}{*}{$\begin{array}{l}H=0,5243 \\
p=0,9135\end{array}$} & & \multirow[t]{2}{*}{1} & \multirow{2}{*}{$\begin{array}{l}1 \\
1\end{array}$} & \multirow{2}{*}{$\begin{array}{l}1 \\
1\end{array}$} \\
\hline & 2 & 1,83 & 0,89 & 0,00 & 1,50 & 1,75 & 2,50 & 3,00 & & 1 & & & \\
\hline & 3 & 1,81 & 0,64 & 0,00 & 1,50 & 2,00 & 2,13 & 3,00 & & 1 & 1 & & 1 \\
\hline & 4 & 1,82 & 0,65 & 0,00 & 1,50 & 2,00 & 2,00 & 3,00 & & 1 & 1 & 1 & \\
\hline \multirow{4}{*}{ Zaprzeczanie } & 1 & 0,96 & 0,71 & 0,00 & 0,50 & 1,00 & 1,50 & 2,50 & \multirow{4}{*}{$\begin{array}{l}H=2,1653 \\
p=0,5388\end{array}$} & & \multirow[t]{2}{*}{1} & 1 & 1 \\
\hline & 2 & 0,86 & 0,82 & 0,00 & 0,50 & 0,50 & 1,50 & 2,50 & & 1 & & \multirow[t]{2}{*}{1} & 1 \\
\hline & 3 & 0,78 & 0,73 & 0,00 & 0,00 & 0,50 & 1,50 & 3,00 & & 1 & 1 & & 1 \\
\hline & 4 & 0,80 & 0,71 & 0,00 & 0,00 & 0,50 & 1,00 & 2,50 & & 1 & 1 & 1 & \\
\hline \multirow{3}{*}{ Wyładowanie } & 1 & 1,22 & 0,67 & 0,00 & 0,50 & 1,25 & 1,50 & 2,50 & \multirow{3}{*}{$\begin{array}{l}H=2,2446 \\
p=0,5232\end{array}$} & & \multirow[t]{2}{*}{1} & 1 & 1 \\
\hline & 2 & 1,14 & 0,76 & 0,00 & 0,50 & 1,00 & 1,50 & 2,50 & & 1 & & 1 & 1 \\
\hline & $\begin{array}{l}3 \\
4\end{array}$ & $\begin{array}{l}1,23 \\
1,34\end{array}$ & $\begin{array}{l}0,75 \\
0,70\end{array}$ & $\begin{array}{l}0,00 \\
0,00\end{array}$ & $\begin{array}{l}0,50 \\
1,00\end{array}$ & $\begin{array}{l}1,25 \\
1,50\end{array}$ & $\begin{array}{l}1,50 \\
2,00\end{array}$ & $\begin{array}{l}3,00 \\
2,50\end{array}$ & & 1 & 1 & 1 & 1 \\
\hline \multirow{4}{*}{$\begin{array}{l}\text { Zażywanie substancji } \\
\text { psychoaktywnych }\end{array}$} & 1 & 0,14 & 0,33 & 0,00 & 0,00 & 0,00 & 0,00 & 1,50 & \multirow{4}{*}{$\begin{array}{l}H=3,9397 \\
p=0,2681\end{array}$} & & \multirow[t]{2}{*}{1} & 1 & \multirow{4}{*}{$\begin{array}{c}0,3188 \\
1 \\
1\end{array}$} \\
\hline & 2 & 0,47 & 0,87 & 0,00 & 0,00 & 0,00 & 0,75 & 2,50 & & 1 & & 1 & \\
\hline & 3 & 0,33 & 0,58 & 0,00 & 0,00 & 0,00 & 0,50 & 2,00 & & 1 & 1 & & \\
\hline & 4 & 0,42 & 0,68 & 0,00 & 0,00 & 0,00 & 1,00 & 3,00 & & 0,3188 & 1 & 1 & \\
\hline \multirow{4}{*}{ Zaprzestanie działań } & 1 & 0,98 & 0,79 & 0,00 & 0,50 & 1,00 & 1,50 & 2,50 & \multirow{4}{*}{$\begin{array}{l}H=8,1792 \\
p=0,0425\end{array}$} & & \multirow[t]{2}{*}{1} & 1 & \multirow{4}{*}{$\begin{array}{c}0,0978 \\
1 \\
0,0943\end{array}$} \\
\hline & 2 & 0,81 & 0,88 & 0,00 & 0,00 & 1,00 & 1,00 & 3,00 & & 1 & & 1 & \\
\hline & 3 & 0,91 & 0,62 & 0,00 & 0,50 & 1,00 & 1,50 & 3,00 & & 1 & 1 & & \\
\hline & 4 & 0,64 & 0,69 & 0,00 & 0,00 & 0,50 & 1,00 & 2,50 & & 0,0978 & 1 & 0,0943 & \\
\hline \multirow{4}{*}{ Obwinianie siebie } & 1 & 0,98 & 0,74 & 0,00 & 0,50 & 1,00 & 1,50 & 3,00 & \multirow{4}{*}{$\begin{array}{l}H=4,5396 \\
p=0,2088\end{array}$} & & \multirow[t]{2}{*}{1} & 1 & 1 \\
\hline & 2 & 0,89 & 0,70 & 0,00 & 0,50 & 1,00 & 1,00 & 2,50 & & 1 & & 1 & 1 \\
\hline & 3 & 1,11 & 0,76 & 0,00 & 0,50 & 1,00 & 1,50 & 2,50 & & 1 & 1 & & 0,2167 \\
\hline & 4 & 0,83 & 0,73 & 0,00 & 0,50 & 1,00 & 1,00 & 3,00 & & 1 & 1 & $0,2167 \mid$ & \\
\hline
\end{tabular}

*1 - Liceum medyczne

*2 - Studium zawodowe

*3 - Licencjat

*4 - Magister

Tabela 6. Strategie radzenia sobie ze stresem wg Mini-COPE ze względu na staż pracy

\begin{tabular}{|c|c|c|c|c|c|c|c|c|c|c|c|c|c|c|}
\hline $\begin{array}{c}\text { Strategie radzenia sobie ze stresem } \\
\text { wg Mini-COPE }\end{array}$ & 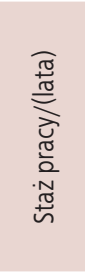 & 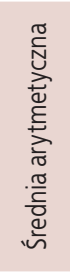 & 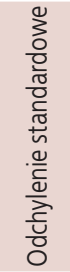 & 㝘 & 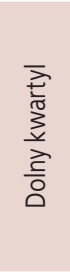 & 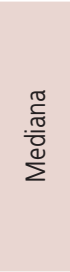 & 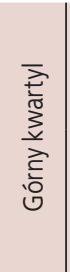 & 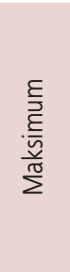 & 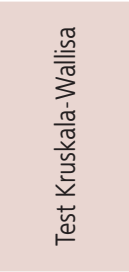 & $\begin{array}{l}\leq 5 \\
\text { lat }\end{array}$ & $\begin{array}{c}6-10 \\
\text { lat }\end{array}$ & $\begin{array}{c}11-15 \\
\text { lat }\end{array}$ & $\begin{array}{c}16-20 \\
\text { lat }\end{array}$ & $\begin{array}{l}\geq 21 \\
\text { lat }\end{array}$ \\
\hline Aktywne radzenie sobie & $\begin{array}{c}\leq 5 \\
6-10 \\
11-15 \\
16-20 \\
\geq 21\end{array}$ & $\begin{array}{l}2,19 \\
2,00 \\
2,31 \\
2,23 \\
2,22\end{array}$ & $\begin{array}{l}0,54 \\
0,69 \\
0,68 \\
0,73 \\
0,62\end{array}$ & $\begin{array}{l}1,00 \\
0,50 \\
1,00 \\
1,00 \\
0,00\end{array}$ & $\begin{array}{l}2,00 \\
1,88 \\
2,00 \\
1,50 \\
2,00\end{array}$ & $\begin{array}{l}2,00 \\
2,00 \\
2,00 \\
2,00 \\
2,00\end{array}$ & $\begin{array}{l}2,50 \\
2,13 \\
3,00 \\
3,00 \\
2,50\end{array}$ & $\begin{array}{l}3,00 \\
3,00 \\
3,00 \\
3,00 \\
3,00\end{array}$ & $\begin{array}{l}H=2,6028 \\
p=0,6263\end{array}$ & $\begin{array}{l}1 \\
1 \\
1 \\
1\end{array}$ & $\begin{array}{l}1 \\
1 \\
1\end{array}$ & $\begin{array}{l}1 \\
1 \\
1 \\
1\end{array}$ & $\begin{array}{l}1 \\
1 \\
1 \\
1\end{array}$ & $\begin{array}{l}1 \\
1 \\
1 \\
1\end{array}$ \\
\hline Planowanie & $\begin{array}{c}\leq 5 \\
6-10 \\
11-15 \\
16-20 \\
\geq 21\end{array}$ & $\begin{array}{l}2,14 \\
2,10 \\
2,13 \\
2,12 \\
2,18\end{array}$ & $\begin{array}{l}0,65 \\
0,50 \\
0,72 \\
0,30 \\
0,71\end{array}$ & $\begin{array}{l}1,00 \\
1,00 \\
1,00 \\
2,00 \\
0,00\end{array}$ & $\begin{array}{l}1,50 \\
2,00 \\
1,88 \\
2,00 \\
2,00\end{array}$ & $\begin{array}{l}2,00 \\
2,00 \\
2,00 \\
2,00 \\
2,00\end{array}$ & $\begin{array}{l}2,50 \\
2,13 \\
2,63 \\
2,00 \\
3,00\end{array}$ & $\begin{array}{l}3,00 \\
3,00 \\
3,00 \\
3,00 \\
3,00\end{array}$ & $\begin{array}{l}H=1,3204 \\
p=0,8579\end{array}$ & $\begin{array}{l}1 \\
1 \\
1 \\
1\end{array}$ & $\begin{array}{l}1 \\
1 \\
1 \\
1\end{array}$ & $\begin{array}{l}1 \\
1 \\
1 \\
1\end{array}$ & $\begin{array}{l}1 \\
1 \\
1 \\
1\end{array}$ & $\begin{array}{l}1 \\
1 \\
1 \\
1\end{array}$ \\
\hline Pozytywne przewartościowanie & $\begin{array}{c}\leq 5 \\
6-10 \\
11-15 \\
16-20 \\
\geq 21\end{array}$ & $\begin{array}{l}1,98 \\
1,75 \\
1,59 \\
1,54 \\
1,82\end{array}$ & $\begin{array}{l}0,76 \\
0,38 \\
0,55 \\
0,85 \\
0,71\end{array}$ & $\begin{array}{l}0,50 \\
1,00 \\
0,50 \\
0,50 \\
0,00\end{array}$ & $\begin{array}{l}1,50 \\
1,50 \\
1,38 \\
1,00 \\
1,38\end{array}$ & $\begin{array}{l}2,00 \\
2,00 \\
1,50 \\
1,50 \\
2,00\end{array}$ & $\begin{array}{l}2,50 \\
2,00 \\
2,00 \\
2,00 \\
2,50\end{array}$ & $\begin{array}{l}3,00 \\
2,50 \\
2,50 \\
3,00 \\
3,00\end{array}$ & $\begin{array}{l}H=5,7542 \\
p=0,2183\end{array}$ & $\left|\begin{array}{c}1 \\
0,5704 \\
0,7866 \\
1\end{array}\right|$ & $\begin{array}{l}1 \\
1 \\
1 \\
1\end{array}$ & $\begin{array}{c}0,5704 \\
1\end{array}$ & $\mid \begin{array}{c}0,7866 \\
1 \\
1 \\
1\end{array}$ & $\begin{array}{l}1 \\
1 \\
1 \\
1\end{array}$ \\
\hline Akceptacja & $\begin{array}{c}\leq 5 \\
6-10 \\
11-15 \\
16-20 \\
\geq 21\end{array}$ & $\begin{array}{l}2,03 \\
1,63 \\
1,72 \\
1,46 \\
1,83\end{array}$ & $\begin{array}{l}0,72 \\
0,48 \\
0,58 \\
1,05 \\
0,71\end{array}$ & $\begin{array}{l}0,00 \\
1,00 \\
0,50 \\
0,00 \\
0,00\end{array}$ & $\begin{array}{l}1,50 \\
1,38 \\
1,50 \\
1,00 \\
1,50\end{array}$ & $\begin{array}{l}2,00 \\
1,50 \\
1,75 \\
1,50 \\
2,00\end{array}$ & $\begin{array}{l}2,50 \\
2,00 \\
2,00 \\
2,00 \\
2,50\end{array}$ & $\begin{array}{l}3,00 \\
2,50 \\
2,50 \\
3,00 \\
3,00\end{array}$ & $\begin{array}{l}H=7,7847 \\
p=0,0998\end{array}$ & $\left|\begin{array}{c}0,1948 \\
1 \\
0,3677 \\
1\end{array}\right|$ & $\begin{array}{l}1 \\
1 \\
1\end{array}$ & $\begin{array}{l}1 \\
1\end{array}$ & $\mid \begin{array}{c}0,3677 \\
1 \\
1 \\
1\end{array}$ & $\begin{array}{l}1 \\
1 \\
1 \\
1\end{array}$ \\
\hline Poczucie humoru & $\begin{array}{c}\leq 5 \\
6-10 \\
11-15 \\
16-20 \\
\geq 21\end{array}$ & $\begin{array}{l}0,81 \\
0,60 \\
0,47 \\
0,81 \\
0,66\end{array}$ & $\begin{array}{l}0,69 \\
0,53 \\
0,50 \\
0,72 \\
0,68\end{array}$ & $\begin{array}{l}0,00 \\
0,00 \\
0,00 \\
0,00 \\
0,00\end{array}$ & $\begin{array}{l}0,50 \\
0,00 \\
0,00 \\
0,50 \\
0,00\end{array}$ & $\begin{array}{l}0,50 \\
0,50 \\
0,50 \\
0,50 \\
0,50\end{array}$ & $\begin{array}{l}1,50 \\
1,00 \\
1,00 \\
1,00 \\
1,00\end{array}$ & $\begin{array}{l}2,00 \\
1,50 \\
1,50 \\
2,50 \\
3,00\end{array}$ & $\begin{array}{l}H=3,3307 \\
p=0,5041\end{array}$ & $\begin{array}{l}1 \\
1 \\
1 \\
1\end{array}$ & $\begin{array}{l}1 \\
1 \\
1\end{array}$ & $\begin{array}{l}1 \\
1\end{array}$ & $\begin{array}{l}1 \\
1 \\
1 \\
1\end{array}$ & $\begin{array}{l}1 \\
1 \\
1 \\
1\end{array}$ \\
\hline Zwrot ku religii & $\begin{array}{c}\leq 5 \\
6-10 \\
11-15 \\
16-20 \\
\geq 21\end{array}$ & $\begin{array}{l}1,16 \\
1,33 \\
1,31 \\
0,81 \\
1,42\end{array}$ & $\begin{array}{l}1,03 \\
0,96 \\
0,95 \\
1,07 \\
0,98\end{array}$ & $\begin{array}{l}0,00 \\
0,00 \\
0,00 \\
0,00 \\
0,00\end{array}$ & $\begin{array}{l}0,00 \\
0,50 \\
0,38 \\
0,00 \\
0,50\end{array}$ & $\begin{array}{l}1,00 \\
1,50 \\
1,75 \\
0,00 \\
1,50\end{array}$ & $\begin{array}{l}1,50 \\
2,00 \\
2,00 \\
1,00 \\
2,00\end{array}$ & $\begin{array}{l}3,00 \\
3,00 \\
2,50 \\
3,00 \\
3,00\end{array}$ & $\begin{array}{l}H=5,8073 \\
p=0,2140\end{array}$ & $\begin{array}{l}1 \\
1 \\
1 \\
1\end{array}$ & $\begin{array}{l}1 \\
1 \\
1\end{array}$ & $\begin{array}{l}1 \\
1\end{array}$ & $\left|\begin{array}{c}1 \\
1 \\
1 \\
0,3010\end{array}\right|$ & $\begin{array}{c}1 \\
1 \\
1 \\
0,3010\end{array}$ \\
\hline
\end{tabular}




\begin{tabular}{|c|c|c|c|c|c|c|c|c|c|c|c|c|c|c|c|}
\hline & $\begin{array}{l}\text { Poszukiwanie wsparcia } \\
\text { emocjonalnego }\end{array}$ & $\begin{array}{c}\leq 5 \\
6-10 \\
11-15 \\
16-20 \\
\geq 21\end{array}$ & \begin{tabular}{|l|}
2,09 \\
2,00 \\
2,03 \\
2,23 \\
1,76
\end{tabular} & $\begin{array}{l}0,79 \\
0,54 \\
0,59 \\
0,48 \\
0,65\end{array}$ & $\left|\begin{array}{l}0,00 \\
1,00 \\
1,00 \\
1,50 \\
0,00\end{array}\right|$ & $\begin{array}{l}1,50 \\
1,88 \\
1,50 \\
2,00 \\
1,50\end{array}$ & $\begin{array}{l}2,00 \\
2,00 \\
2,00 \\
2,00 \\
2,00\end{array}$ & $\begin{array}{l}3,00 \\
2,13 \\
2,50 \\
2,50 \\
2,00\end{array}$ & $\begin{array}{l}3,00 \\
3,00 \\
3,00 \\
3,00 \\
3,00\end{array}$ & $\begin{array}{l}H=11,074 \\
p=0,0257\end{array}$ & \begin{tabular}{|c|}
1 \\
1 \\
1 \\
0,1743
\end{tabular} & $\begin{array}{l}1 \\
1 \\
1 \\
1\end{array}$ & $\begin{array}{l}1 \\
1\end{array}$ & $\left|\begin{array}{c}1 \\
1 \\
1 \\
0,1577\end{array}\right|$ & $\begin{array}{c}0,1743 \\
1 \\
1 \\
0,1577\end{array}$ \\
\hline & $\begin{array}{l}\text { Poszukiwanie wsparcia } \\
\text { instrumentalnego }\end{array}$ & $\begin{array}{c}\leq 5 \\
6-10 \\
11-15 \\
16-20 \\
\geq 21 \text { lat }\end{array}$ & \begin{tabular}{|l|}
1,95 \\
1,98 \\
1,88 \\
1,96 \\
1,80
\end{tabular} & $\begin{array}{l}0,79 \\
0,64 \\
0,70 \\
0,48 \\
0,65\end{array}$ & \begin{tabular}{|l|}
0,00 \\
1,00 \\
0,50 \\
0,50 \\
0,00
\end{tabular} & $\begin{array}{l}1,50 \\
1,50 \\
1,50 \\
2,00 \\
1,50\end{array}$ & $\begin{array}{l}2,00 \\
2,00 \\
2,00 \\
2,00 \\
2,00\end{array}$ & $\begin{array}{l}2,50 \\
2,50 \\
2,13 \\
2,00 \\
2,00\end{array}$ & $\begin{array}{l}3,00 \\
3,00 \\
3,00 \\
2,50 \\
3,00\end{array}$ & $\begin{array}{l}H=3,2870 \\
p=0,5110\end{array}$ & $\begin{array}{l}1 \\
1 \\
1 \\
1\end{array}$ & $\begin{array}{l}1 \\
1 \\
1 \\
1\end{array}$ & $\begin{array}{l}1 \\
1 \\
1 \\
1\end{array}$ & $\begin{array}{l}1 \\
1 \\
1 \\
1\end{array}$ & $\begin{array}{l}1 \\
1 \\
1 \\
1\end{array}$ \\
\hline & Zajmowanie się czymś innym & \begin{tabular}{|c|}
$\leq 5$ \\
$6-10$ \\
$11-15$ \\
$16-20$ \\
$\geq 21$
\end{tabular} & $\begin{array}{l}1,83 \\
1,83 \\
1,97 \\
1,73 \\
1,85\end{array}$ & $\begin{array}{l}0,71 \\
0,57 \\
0,62 \\
0,81 \\
0,75\end{array}$ & $\begin{array}{l}0,50 \\
0,50 \\
1,00 \\
0,00 \\
0,00\end{array}$ & $\begin{array}{l}1,50 \\
1,88 \\
1,50 \\
1,50 \\
1,50\end{array}$ & $\begin{array}{l}2,00 \\
2,00 \\
2,00 \\
2,00 \\
2,00\end{array}$ & $\begin{array}{l}2,50 \\
2,00 \\
2,50 \\
2,00 \\
2,50\end{array}$ & $\begin{array}{l}3,00 \\
2,50 \\
3,00 \\
3,00 \\
3,00\end{array}$ & $\begin{array}{l}H=0,5382 \\
p=0,9697\end{array}$ & $\begin{array}{l}1 \\
1 \\
1 \\
1\end{array}$ & $\begin{array}{l}1 \\
1 \\
1 \\
1\end{array}$ & $\begin{array}{l}1 \\
1 \\
1 \\
1\end{array}$ & $\begin{array}{l}1 \\
1 \\
1 \\
1\end{array}$ & $\begin{array}{l}1 \\
1 \\
1 \\
1\end{array}$ \\
\hline & Zaprzeczanie & $\begin{array}{c}\leq 5 \\
6-10 \\
11-15 \\
16-20 \\
\geq 21\end{array}$ & \begin{tabular}{|c|}
0,74 \\
0,88 \\
0,91 \\
0,85 \\
0,86
\end{tabular} & $\begin{array}{l}0,64 \\
0,70 \\
0,80 \\
0,94 \\
0,72\end{array}$ & $\begin{array}{l}0,00 \\
0,00 \\
0,00 \\
0,00 \\
0,00\end{array} \mid$ & $\begin{array}{l}0,00 \\
0,50 \\
0,38 \\
0,50 \\
0,38\end{array}$ & $\begin{array}{l}0,50 \\
0,75 \\
0,50 \\
0,50 \\
1,00\end{array}$ & $\begin{array}{l}1,00 \\
1,50 \\
1,63 \\
1,00 \\
1,50\end{array}$ & $\begin{array}{l}2,00 \\
2,50 \\
2,00 \\
3,00 \\
2,50\end{array}$ & $\begin{array}{l}H=0,7526 \\
p=0,9447\end{array}$ & $\begin{array}{l}1 \\
1 \\
1 \\
1\end{array}$ & $\begin{array}{l}1 \\
1 \\
1\end{array}$ & $\begin{array}{l}1 \\
1 \\
1 \\
1\end{array}$ & $\begin{array}{l}1 \\
1 \\
1 \\
1\end{array}$ & $\begin{array}{l}1 \\
1 \\
1 \\
1\end{array}$ \\
\hline & Wyładowanie & $\begin{array}{c}\leq 5 \\
6-10 \\
11-15 \\
16-20 \\
\geq 21\end{array}$ & \begin{tabular}{|c|}
1,34 \\
1,30 \\
1,19 \\
1,54 \\
1,19 \\
\end{tabular} & $\begin{array}{l}0,72 \\
0,59 \\
0,93 \\
0,78 \\
0,68\end{array}$ & \begin{tabular}{|l|}
0,00 \\
0,00 \\
0,00 \\
0,00 \\
0,00
\end{tabular} & $\begin{array}{l}1,00 \\
1,00 \\
0,38 \\
1,00 \\
0,50\end{array}$ & $\begin{array}{l}1,50 \\
1,50 \\
1,25 \\
1,50 \\
1,00\end{array}$ & $\begin{array}{l}1,50 \\
1,63 \\
2,00 \\
2,00 \\
1,50\end{array}$ & $\begin{array}{l}3,00 \\
2,00 \\
2,50 \\
2,50 \\
2,50\end{array}$ & $\begin{array}{l}H=3,1477 \\
p=0,5334\end{array}$ & $\begin{array}{l}1 \\
1 \\
1 \\
1\end{array}$ & $\begin{array}{l}1 \\
1 \\
1 \\
1\end{array}$ & $\begin{array}{l}1 \\
1 \\
1 \\
1\end{array}$ & $\begin{array}{l}1 \\
1 \\
1\end{array}$ & $\begin{array}{l}1 \\
1 \\
1 \\
1\end{array}$ \\
\hline & $\begin{array}{l}\text { Zażywanie substancji } \\
\text { psychoaktywnych }\end{array}$ & $\begin{array}{c}\leq 5 \\
6-10 \\
11-15 \\
16-20 \\
\geq 21\end{array}$ & \begin{tabular}{|l|}
0,38 \\
0,40 \\
0,16 \\
0,42 \\
0,31
\end{tabular} & $\begin{array}{l}0,64 \\
0,66 \\
0,35 \\
0,53 \\
0,63\end{array}$ & $\begin{array}{l}0,00 \\
0,00 \\
0,00 \\
0,00 \\
0,00\end{array}$ & $\begin{array}{l}0,00 \\
0,00 \\
0,00 \\
0,00 \\
0,00\end{array}$ & $\begin{array}{l}0,00 \\
0,00 \\
0,00 \\
0,00 \\
0,00\end{array}$ & $\begin{array}{l}1,00 \\
1,00 \\
0,00 \\
1,00 \\
0,50\end{array}$ & $\begin{array}{l}2,00 \\
2,00 \\
1,00 \\
1,50 \\
3,00\end{array}$ & $\begin{array}{l}H=2,9141 \\
p=0,5723\end{array}$ & $\begin{array}{l}1 \\
1 \\
1 \\
1\end{array}$ & $\begin{array}{l}1 \\
1 \\
1\end{array}$ & $\begin{array}{l}1 \\
1\end{array}$ & $\begin{array}{l}1 \\
1 \\
1 \\
1\end{array}$ & $\begin{array}{l}1 \\
1 \\
1 \\
1\end{array}$ \\
\hline $\mathrm{O}_{2}^{2}$ & Zaprzestanie działań & $\begin{array}{c}\leq 5 \\
6-10 \\
11-15 \\
16-20 \\
\geq 21\end{array}$ & \begin{tabular}{|l|}
0,98 \\
0,78 \\
0,44 \\
0,69 \\
0,89
\end{tabular} & $\begin{array}{l}0,53 \\
0,66 \\
0,63 \\
0,72 \\
0,79\end{array}$ & $\begin{array}{l}0,00 \\
0,00 \\
0,00 \\
0,00 \\
0,00\end{array}$ & $\begin{array}{l}0,50 \\
0,38 \\
0,00 \\
0,00 \\
0,00\end{array}$ & $\begin{array}{l}1,00 \\
0,75 \\
0,00 \\
0,50 \\
1,00\end{array}$ & $\begin{array}{l}1,50 \\
1,00 \\
0,63 \\
1,00 \\
1,50\end{array}$ & $\begin{array}{l}2,00 \\
2,50 \\
2,00 \\
2,50 \\
3,00\end{array}$ & $\begin{array}{l}H=9,3865 \\
p=0,0521\end{array}$ & $\begin{array}{c}1 \\
0,0356 \\
1 \\
1\end{array}$ & $\begin{array}{l}1 \\
1 \\
1\end{array}$ & $\begin{array}{c}0,0356 \\
1 \\
1 \\
0,1757\end{array}$ & $\begin{array}{l}1 \\
1 \\
1\end{array}$ & $\begin{array}{c}1 \\
1 \\
0,1757 \\
1\end{array}$ \\
\hline & Obwinianie siebie & $\begin{array}{c}\leq 5 \\
6-10 \\
11-15 \\
16-20 \\
\geq 21\end{array}$ & \begin{tabular}{|l|}
1,29 \\
1,20 \\
0,66 \\
0,50 \\
0,94
\end{tabular} & $\begin{array}{l}0,82 \\
0,78 \\
0,75 \\
0,46 \\
0,71\end{array}$ & $\begin{array}{l}0,00 \\
0,00 \\
0,00 \\
0,00 \\
0,00\end{array}$ & $\begin{array}{l}1,00 \\
0,88 \\
0,00 \\
0,00 \\
0,50\end{array}$ & $\begin{array}{l}1,50 \\
1,00 \\
0,50 \\
0,50 \\
1,00\end{array}$ & $\begin{array}{l}1,50 \\
1,63 \\
1,13 \\
0,50 \\
1,50\end{array}$ & $\begin{array}{l}3,00 \\
3,00 \\
2,00 \\
1,50 \\
3,00\end{array}$ & $\begin{array}{l}H=15,797 \\
p=0,0033\end{array}$ & $\begin{array}{c}1 \\
0,0616 \\
0,013 \\
0,3254\end{array}$ & $\begin{array}{c}0,2502 \\
0,0637 \\
1\end{array}$ & $\begin{array}{l}0,0616 \\
0,2502\end{array}$ & $\left|\begin{array}{c}0,013 \\
0,0637 \\
1 \\
0,3585\end{array}\right|$ & $\begin{array}{c}0,3254 \\
1 \\
1 \\
0,3585\end{array}$ \\
\hline
\end{tabular}

Tabela 7. Strategie radzenia sobie ze stresem wg Mini-COPE ze względu na poziom satysfakcji z pracy zawodowej

\begin{tabular}{|c|c|c|c|c|c|c|c|c|c|}
\hline $\begin{array}{l}\text { Strategie radzenia sobie ze stresem } \\
\text { wg Mini-COPE }\end{array}$ & 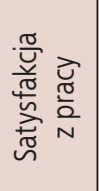 & 它 & 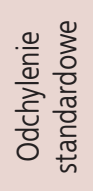 & 忘 & 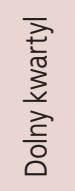 & $\begin{array}{l}\stackrel{0}{\stackrel{D}{0}} \\
\stackrel{\frac{0}{0}}{\Sigma}\end{array}$ & 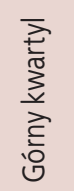 & $\begin{array}{l}\frac{E}{5} \\
\frac{E}{\sqrt{n}} \\
\frac{\underline{v}}{\Sigma}\end{array}$ & 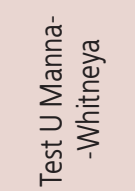 \\
\hline \multirow{2}{*}{ Aktywne radzenie sobie } & Nie & 2,12 & 0,65 & 1,00 & 1,50 & 2,00 & 2,50 & 3,00 & $Z=0,5493$ \\
\hline & Tak & 2,21 & 0,63 & 0,00 & 2,00 & 2,00 & 2,50 & 3,00 & $p=0,5828$ \\
\hline \multirow{2}{*}{ Planowanie } & Nie & 2,21 & 0,71 & 1,00 & 1,50 & 2,50 & 3,00 & 3,00 & $Z=0,3576$ \\
\hline & Tak & 2,15 & 0,65 & 0,00 & 2,00 & 2,00 & 2,50 & 3,00 & $p=0,7207$ \\
\hline \multirow{2}{*}{ Pozytywne przewartościowanie } & Nie & 1,44 & 0,66 & 0,50 & 1,00 & 1,50 & 2,00 & 2,50 & $Z=2,2185$ \\
\hline & Tak & 1,84 & 0,69 & 0,00 & 1,50 & 2,00 & 2,50 & 3,00 & $p=0,0265$ \\
\hline \multirow{2}{*}{ Akceptacja } & Nie & 1,85 & 0,86 & 0,00 & 1,50 & 2,00 & 2,50 & 3,00 & $Z=0,3712$ \\
\hline & Tak & 1,80 & 0,70 & 0,00 & 1,50 & 2,00 & 2,50 & 3,00 & $\mathrm{p}=0,7105$ \\
\hline \multirow{2}{*}{ Poczucie humoru } & Nie & 0,79 & 0,87 & 0,00 & 0,00 & 0,50 & 1,00 & 2,50 & $Z=0,2783$ \\
\hline & Tak & 0,66 & 0,63 & 0,00 & 0,00 & 0,50 & 1,00 & 3,00 & $p=0,7808$ \\
\hline \multirow{2}{*}{ Zwrot ku religii } & $\mathrm{Nie}$ & 0,74 & 0,95 & 0,00 & 0,00 & 0,00 & 1,00 & 2,50 & $Z=2,5384$ \\
\hline & Tak & 1,37 & 0,98 & 0,00 & 0,50 & 1,50 & 2,00 & 3,00 & $p=0,0111$ \\
\hline \multirow{2}{*}{ Poszukiwanie wsparcia emocjonalnego } & Nie & 1,56 & 0,73 & 0,00 & 1,00 & 2,00 & 2,00 & 3,00 & $Z=2,0614$ \\
\hline & Tak & 1,94 & 0,65 & 0,00 & 1,50 & 2,00 & 2,50 & 3,00 & $p=0,0393$ \\
\hline
\end{tabular}




\begin{tabular}{|l|c|c|c|c|c|c|c|c|c|}
\hline \multirow{2}{*}{ Poszukiwanie wsparcia instrumentalnego } & Nie & 1,47 & 0,72 & 0,00 & 1,00 & 1,50 & 2,00 & 3,00 & $Z=2,3861$ \\
Zajmowanie się czymś innym & Tak & 1,91 & 0,65 & 0,00 & 1,50 & 2,00 & 2,50 & 3,00 & $p=0,0170$ \\
Zaprzeczanie & Nie & 1,85 & 0,82 & 0,00 & 1,50 & 2,00 & 2,50 & 3,00 & $Z=0,4104$ \\
Wyładowanie & Tak & 1,85 & 0,70 & 0,00 & 1,50 & 2,00 & 2,50 & 3,00 & $p=0,6815$ \\
& Nie & 0,62 & 0,88 & 0,00 & 0,00 & 0,50 & 0,50 & 3,00 & $Z=1,9114$ \\
Zażywanie substancji psychoaktywnych & Tak & 0,87 & 0,71 & 0,00 & 0,50 & 1,00 & 1,50 & 2,50 & $p=0,0560$ \\
& Nie & 1,35 & 0,77 & 0,00 & 1,00 & 1,50 & 1,50 & 3,00 & $Z=0,4923$ \\
Zaprzestanie działań & Tak & 1,25 & 0,71 & 0,00 & 0,50 & 1,50 & 1,50 & 2,50 & $p=0,6225$ \\
Obwinianie siebie & Nie & 0,41 & 0,69 & 0,00 & 0,00 & 0,00 & 0,50 & 2,00 & $Z=0,6405$ \\
& Tak & 0,32 & 0,60 & 0,00 & 0,00 & 0,00 & 0,50 & 3,00 & $p=0,5219$ \\
& Nie & 0,88 & 0,74 & 0,00 & 0,00 & 1,00 & 1,50 & 2,50 & $Z=0,4002$ \\
& Tak & 0,83 & 0,73 & 0,00 & 0,00 & 0,50 & 1,50 & 3,00 & $p=0,6890$ \\
& Nie & 1,15 & 0,88 & 0,00 & 0,50 & 1,00 & 1,50 & 3,00 & $Z=0,8374$ \\
& Tak & 0,95 & 0,74 & 0,00 & 0,50 & 1,00 & 1,50 & 3,00 & $p=0,4023$
\end{tabular}

Tabela 8. Strategie radzenia sobie ze stresem wg Mini-COPE ze względu na brak współpracy w zespole terapeutycznym

\begin{tabular}{|c|c|c|c|c|c|c|c|c|c|}
\hline $\begin{array}{l}\text { Strategie radzenia sobie ze stresem } \\
\text { wg Mini-COPE }\end{array}$ & 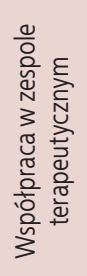 & 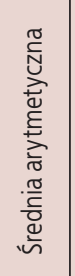 & 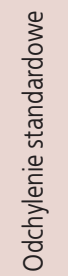 & 忘 & 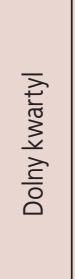 & 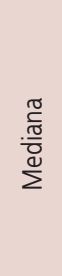 & 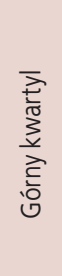 & 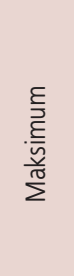 & 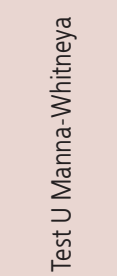 \\
\hline Aktywne radzenie sobie & $\begin{array}{l}\text { Nie } \\
\text { Tak }\end{array}$ & $\begin{array}{l}2,25 \\
2,03\end{array}$ & $\begin{array}{l}0,64 \\
0,55\end{array}$ & $\begin{array}{l}0,00 \\
0,50\end{array}$ & $\begin{array}{l}2,00 \\
1,88\end{array}$ & 2,50 & 3,00 & $\begin{array}{l}3,00 \\
3,00\end{array}$ & $\mathrm{Z}=2,3735$ \\
\hline Planowanie & $\begin{array}{l}\text { Nie } \\
\text { Tak }\end{array}$ & $\begin{array}{l}2,18 \\
2,09\end{array}$ & $\begin{array}{l}0,66 \\
0,63\end{array}$ & $\begin{array}{l}0,00 \\
1,00\end{array}$ & $\begin{array}{l}2,00 \\
1,88\end{array}$ & $\begin{array}{l}2,00 \\
2,00\end{array}$ & $\begin{array}{l}2,88 \\
2,50\end{array}$ & $\begin{array}{l}3,00 \\
3,00\end{array}$ & $\begin{array}{l}Z=0,8262 \\
p=0,4087\end{array}$ \\
\hline Pozytywne przewartościowanie & $\begin{array}{l}\text { Nie } \\
\text { Tak }\end{array}$ & $\begin{array}{l}1,81 \\
1,77\end{array}$ & $\begin{array}{l}0,69 \\
0,69\end{array}$ & $\begin{array}{l}0,00 \\
0,50\end{array}$ & $\begin{array}{l}1,50 \\
1,38\end{array}$ & $\begin{array}{l}2,00 \\
2,00\end{array}$ & $\begin{array}{l}2,50 \\
2,00\end{array}$ & $\begin{array}{l}3,00 \\
3,00\end{array}$ & $\begin{array}{l}Z=0,5152 \\
p=0,6064\end{array}$ \\
\hline Akceptacja & $\begin{array}{l}\text { Nie } \\
\text { Tak }\end{array}$ & $\begin{array}{l}1,78 \\
1,86\end{array}$ & $\begin{array}{l}0,70 \\
0,76\end{array}$ & $\begin{array}{l}0,00 \\
0,00\end{array}$ & $\begin{array}{l}1,50 \\
1,50\end{array}$ & $\begin{array}{l}2,00 \\
2,00\end{array}$ & $\begin{array}{l}2,50 \\
2,50\end{array}$ & $\begin{array}{l}3,00 \\
3,00\end{array}$ & $\begin{array}{l}Z=0,5053 \\
p=0,6133\end{array}$ \\
\hline Poczucie humoru & $\begin{array}{l}\text { Nie } \\
\text { Tak }\end{array}$ & $\begin{array}{l}0,63 \\
0,80\end{array}$ & $\begin{array}{l}0,62 \\
0,74\end{array}$ & $\begin{array}{l}0,00 \\
0,00\end{array}$ & $\begin{array}{l}0,00 \\
0,38\end{array}$ & $\begin{array}{l}0,50 \\
0,50\end{array}$ & $\begin{array}{l}1,00 \\
1,13\end{array}$ & $\begin{array}{l}2,50 \\
3,00\end{array}$ & $\begin{array}{l}Z=1,2087 \\
p=0,2268\end{array}$ \\
\hline Zwrot ku religii & $\begin{array}{l}\text { Nie } \\
\text { Tak }\end{array}$ & $\begin{array}{l}1,35 \\
1,19\end{array}$ & $\begin{array}{l}0,97 \\
1,05\end{array}$ & $\begin{array}{l}0,00 \\
0,00\end{array}$ & $\begin{array}{l}0,50 \\
0,00\end{array}$ & $\begin{array}{l}1,50 \\
1,00\end{array}$ & $\begin{array}{l}2,00 \\
2,00\end{array}$ & $\begin{array}{l}3,00 \\
3,00\end{array}$ & $\begin{array}{l}Z=1,0365 \\
p=0,3000\end{array}$ \\
\hline Poszukiwanie wsparcia emocjonalnego & $\begin{array}{l}\text { Nie } \\
\text { Tak }\end{array}$ & $\begin{array}{l}1,92 \\
1,86\end{array}$ & $\begin{array}{l}0,66 \\
0,69\end{array}$ & $\begin{array}{l}0,00 \\
0,00\end{array}$ & $\begin{array}{l}1,50 \\
1,50\end{array}$ & $\begin{array}{l}2,00 \\
2,00\end{array}$ & $\begin{array}{l}2,50 \\
2,00\end{array}$ & $\begin{array}{l}3,00 \\
3,00\end{array}$ & $\begin{array}{l}Z=0,4187 \\
p=0,6755\end{array}$ \\
\hline Poszukiwanie wsparcia instrumentalnego & $\begin{array}{l}\text { Nie } \\
\text { Tak }\end{array}$ & $\begin{array}{l}1,87 \\
1,85\end{array}$ & $\begin{array}{l}0,67 \\
0,67\end{array}$ & $\begin{array}{l}0,00 \\
0,00\end{array}$ & $\begin{array}{l}1,50 \\
1,50\end{array}$ & $\begin{array}{l}2,00 \\
2,00\end{array}$ & $\begin{array}{l}2,50 \\
2,00\end{array}$ & $\begin{array}{l}3,00 \\
3,00\end{array}$ & $\begin{array}{l}Z=0,0232 \\
p=0,9815\end{array}$ \\
\hline Zajmowanie się czymś innym & $\begin{array}{l}\text { Nie } \\
\text { Tak }\end{array}$ & $\begin{array}{l}1,75 \\
2,13\end{array}$ & $\begin{array}{l}0,73 \\
0,55\end{array}$ & $\begin{array}{l}0,00 \\
1,00\end{array}$ & $\begin{array}{l}1,50 \\
1,50\end{array}$ & $\begin{array}{l}2,00 \\
2,00\end{array}$ & $\begin{array}{l}2,00 \\
2,50\end{array}$ & $\begin{array}{l}3,00 \\
3,00\end{array}$ & $\begin{array}{l}Z=2,9278 \\
p=0,0034\end{array}$ \\
\hline Zaprzeczanie & $\begin{array}{l}\text { Nie } \\
\text { Tak }\end{array}$ & $\begin{array}{l}0,87 \\
0,80\end{array}$ & $\begin{array}{l}0,74 \\
0,70\end{array}$ & $\begin{array}{l}0,00 \\
0,00\end{array}$ & $\begin{array}{l}0,50 \\
0,38\end{array}$ & $\begin{array}{l}0,50 \\
0,50\end{array}$ & $\begin{array}{l}1,50 \\
1,13\end{array}$ & $\begin{array}{l}2,50 \\
3,00\end{array}$ & $\begin{array}{l}Z=0,4967 \\
p=0,6194\end{array}$ \\
\hline Wyładowanie & $\begin{array}{l}\text { Nie } \\
\text { Tak }\end{array}$ & $\begin{array}{l}1,22 \\
1,35\end{array}$ & $\begin{array}{l}0,71 \\
0,71\end{array}$ & $\begin{array}{l}0,00 \\
0,00\end{array}$ & $\begin{array}{l}0,50 \\
0,88\end{array}$ & $\begin{array}{l}1,25 \\
1,50\end{array}$ & $\begin{array}{l}1,50 \\
2,00\end{array}$ & $\begin{array}{l}2,50 \\
3,00\end{array}$ & $\begin{array}{c}Z=1,1293 \\
p=0,2588\end{array}$ \\
\hline Zażywanie substancji psychoaktywnych & $\begin{array}{l}\text { Nie } \\
\text { Tak }\end{array}$ & $\begin{array}{l}0,33 \\
0,33\end{array}$ & $\begin{array}{l}0,60 \\
0,62\end{array}$ & $\begin{array}{l}0,00 \\
0,00\end{array}$ & $\begin{array}{l}0,00 \\
0,00\end{array}$ & $\begin{array}{l}0,00 \\
0,00\end{array}$ & $\begin{array}{l}0,50 \\
0,50\end{array}$ & $\begin{array}{l}3,00 \\
2,50\end{array}$ & $\begin{array}{l}Z=0,0809 \\
p=0,9355\end{array}$ \\
\hline Zaprzestanie działań & $\begin{array}{l}\text { Nie } \\
\text { Tak }\end{array}$ & $\begin{array}{l}0,89 \\
0,67\end{array}$ & $\begin{array}{l}0,78 \\
0,52\end{array}$ & $\begin{array}{l}0,00 \\
0,00\end{array}$ & $\begin{array}{l}0,00 \\
0,50\end{array}$ & $\begin{array}{l}1,00 \\
0,50\end{array}$ & $\begin{array}{l}1,50 \\
1,00\end{array}$ & $\begin{array}{l}3,00 \\
1,50\end{array}$ & $\begin{array}{l}Z=1,2906 \\
p=0,1969\end{array}$ \\
\hline Obwinianie siebie & $\begin{array}{l}\text { Nie } \\
\text { Tak }\end{array}$ & $\begin{array}{l}0,97 \\
0,99\end{array}$ & $\begin{array}{l}0,75 \\
0,77\end{array}$ & $\begin{array}{l}0,00 \\
0,00\end{array}$ & $\begin{array}{l}0,50 \\
0,50\end{array}$ & $\begin{array}{l}1,00 \\
1,00\end{array}$ & $\begin{array}{l}1,50 \\
1,50\end{array}$ & $\begin{array}{l}3,00 \\
3,00\end{array}$ & $\begin{array}{l}Z=0,2781 \\
p=0,7810\end{array}$ \\
\hline
\end{tabular}


$(p<0,05)$ oraz "zajmowanie się czymś innym" ( $p<0,01)$. Pozostałe strategie skali Mini-COPE nie miały związku $z$ analizowaną zmienną $(p>0,05)$ - tabela 8. Nie wykazano znamiennej statystycznie różnicy między wyborem strategii radzenia sobie ze stresem a brakiem wsparcia ze strony przełożonych $(p>0,05)$ - tabela 9 . Objawy somatyczne $w$ badanej próbie miały istotny związek $z$ wyborem strategii radzenia sobie ze stresem. Personel pielęgniarski, który deklarował bóle kręgosłupa, wybierał strategię „akceptacja" ( $p<0,05)$, zaś pracownicy, którzy doświadczyli bólu w klatce piersiowej - „pozytywne przewartościowanie" $(p<0,05)$. Zawroty i bóle głowy w badanej próbie warunkowały istotnie wybór strategii unikowej - „zaprzeczanie"( $p<0,01)$. Zmienna psychiczna - uczucie gniewu warunkowała wybór strategii unikowych - „wyładowanie" oraz "zażywanie substancji psychoaktywnych". Uczucie bezradności/bezsilności było predyktorem stylów „pozytywne przewartościowanie” oraz „zażywanie substancj psychoaktywnych", natomiast uczucie osłabienia/braku sił w istotny sposób istotnie determinowało strategię radzenia sobie ze stresem - „poszukiwanie wsparcia emocjonalnego". Pozostałe zmienne psychiczne: obniżony nastrój, brak energii do działania nie miały związku z wyborem żadnej strategii radzenia sobie ze stresem.

Tabela 9. Strategie radzenia sobie ze stresem wg Mini-COPE ze względu na brak wsparcia ze strony przełożonych

\begin{tabular}{|c|c|c|c|c|c|c|c|c|c|}
\hline $\begin{array}{l}\text { Strategie radzenia sobie ze stresem } \\
\text { wg Mini-COPE }\end{array}$ & 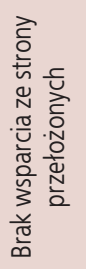 & 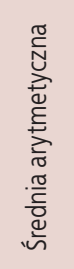 & 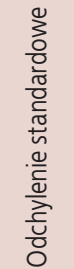 & 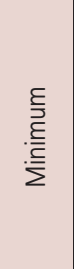 & 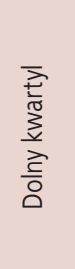 & 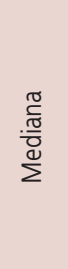 & 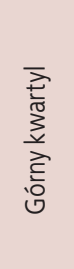 & 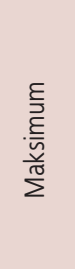 & 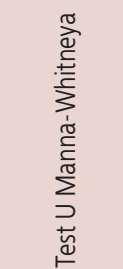 \\
\hline Aktywne radzenie sobie & $\begin{array}{l}\text { Nie } \\
\text { Tak }\end{array}$ & $\begin{array}{l}2,22 \\
2,11\end{array}$ & $\begin{array}{l}0,65 \\
0,52\end{array}$ & $\begin{array}{l}0,00 \\
1,00\end{array}$ & $\begin{array}{l}2,00 \\
2,00\end{array}$ & $\begin{array}{l}2,00 \\
2,00\end{array}$ & $\begin{array}{l}3,00 \\
2,50\end{array}$ & $\begin{array}{l}3,00 \\
3,00\end{array}$ & $\begin{array}{l}Z=1,3600 \\
p=0,1738\end{array}$ \\
\hline Planowanie & $\begin{array}{l}\text { Nie } \\
\text { Tak }\end{array}$ & $\begin{array}{l}2,17 \\
2,11\end{array}$ & $\begin{array}{l}0,68 \\
0,55\end{array}$ & $\begin{array}{l}0,00 \\
1,00\end{array}$ & $\begin{array}{l}2,00 \\
2,00\end{array}$ & $\begin{array}{l}2,00 \\
2,00\end{array}$ & $\begin{array}{l}3,00 \\
2,50\end{array}$ & $\begin{array}{l}3,00 \\
3,00\end{array}$ & $\begin{array}{l}Z=0,7445 \\
p=0,4566\end{array}$ \\
\hline Pozytywne przewartościowanie & $\begin{array}{l}\text { Nie } \\
\text { Tak }\end{array}$ & $\begin{array}{l}1,77 \\
1,91\end{array}$ & $\begin{array}{l}0,71 \\
0,62\end{array}$ & $\begin{array}{l}0,00 \\
0,50\end{array}$ & $\begin{array}{l}1,00 \\
1,50\end{array}$ & $\begin{array}{l}2,00 \\
2,00\end{array}$ & $\begin{array}{l}2,50 \\
2,38\end{array}$ & $\begin{array}{l}3,00 \\
3,00\end{array}$ & $\begin{array}{l}Z=0,9140 \\
p=0,3607\end{array}$ \\
\hline Akceptacja & $\begin{array}{l}\text { Nie } \\
\text { Tak }\end{array}$ & $\begin{array}{l}1,83 \\
1,71\end{array}$ & $\begin{array}{l}0,71 \\
0,72\end{array}$ & $\begin{array}{l}0,00 \\
0,00\end{array}$ & $\begin{array}{l}1,50 \\
1,13\end{array}$ & $\begin{array}{l}2,00 \\
1,50\end{array}$ & $\begin{array}{l}2,50 \\
2,00\end{array}$ & $\begin{array}{l}3,00 \\
3,00\end{array}$ & $\begin{array}{l}Z=1,0446 \\
p=0,2962\end{array}$ \\
\hline Poczucie humoru & $\begin{array}{l}\text { Nie } \\
\text { Tak }\end{array}$ & $\begin{array}{l}0,68 \\
0,62\end{array}$ & $\begin{array}{l}0,67 \\
0,57\end{array}$ & $\begin{array}{l}0,00 \\
0,00\end{array}$ & $\begin{array}{l}0,00 \\
0,00\end{array}$ & $\begin{array}{l}0,50 \\
0,50\end{array}$ & $\begin{array}{l}1,00 \\
1,00\end{array}$ & $\begin{array}{l}3,00 \\
2,00\end{array}$ & $\begin{array}{l}Z=0,2755 \\
p=0,7830\end{array}$ \\
\hline Zwrot ku religii & $\begin{array}{l}\text { Nie } \\
\text { Tak }\end{array}$ & $\begin{array}{l}1,33 \\
1,21\end{array}$ & $\begin{array}{l}0,99 \\
1,00\end{array}$ & $\begin{array}{l}0,00 \\
0,00\end{array}$ & $\begin{array}{l}0,50 \\
0,00\end{array}$ & $\begin{array}{l}1,25 \\
1,00\end{array}$ & $\begin{array}{l}2,00 \\
2,00\end{array}$ & $\begin{array}{l}3,00 \\
3,00\end{array}$ & $\begin{array}{l}Z=0,6229 \\
p=0,5334\end{array}$ \\
\hline Poszukiwanie wsparcia emocjonalnego & $\begin{array}{l}\text { Nie } \\
\text { Tak }\end{array}$ & $\begin{array}{l}1,92 \\
1,86\end{array}$ & $\begin{array}{l}0,68 \\
0,61\end{array}$ & $\begin{array}{l}0,00 \\
0,50\end{array}$ & $\begin{array}{l}1,50 \\
1,50\end{array}$ & $\begin{array}{l}2,00 \\
2,00\end{array}$ & $\begin{array}{l}2,50 \\
2,38\end{array}$ & $\begin{array}{l}3,00 \\
3,00\end{array}$ & $\begin{array}{l}Z=0,5063 \\
p=0,6126\end{array}$ \\
\hline Poszukiwanie wsparcia instrumentalnego & $\begin{array}{l}\text { Nie } \\
\text { Tak }\end{array}$ & $\begin{array}{l}1,85 \\
1,92\end{array}$ & $\begin{array}{l}0,70 \\
0,51\end{array}$ & $\begin{array}{l}0,00 \\
1,00\end{array}$ & $\begin{array}{l}1,50 \\
1,50\end{array}$ & $\begin{array}{l}2,00 \\
2,00\end{array}$ & $\begin{array}{l}2,50 \\
2,00\end{array}$ & $\begin{array}{l}3,00 \\
3,00\end{array}$ & $\begin{array}{l}Z=0,4526 \\
p=0,6508\end{array}$ \\
\hline Zajmowanie się czymś innym & $\begin{array}{l}\text { Nie } \\
\text { Tak }\end{array}$ & $\begin{array}{l}1,80 \\
2,03\end{array}$ & $\begin{array}{l}0,70 \\
0,73\end{array}$ & $\begin{array}{l}0,00 \\
0,00\end{array}$ & $\begin{array}{l}1,50 \\
1,50\end{array}$ & $\begin{array}{l}2,00 \\
2,00\end{array}$ & $\begin{array}{l}2,00 \\
2,50\end{array}$ & $\begin{array}{l}3,00 \\
3,00\end{array}$ & $\begin{array}{l}Z=1,8985 \\
p=0,0576\end{array}$ \\
\hline Zaprzeczanie & $\begin{array}{l}\text { Nie } \\
\text { Tak }\end{array}$ & $\begin{array}{l}0,81 \\
1,00\end{array}$ & $\begin{array}{l}0,72 \\
0,74\end{array}$ & $\begin{array}{l}0,00 \\
0,00\end{array}$ & $\begin{array}{l}0,00 \\
0,50\end{array}$ & $\begin{array}{l}0,50 \\
1,00\end{array}$ & $\begin{array}{l}1,00 \\
1,50\end{array}$ & $\begin{array}{l}3,00 \\
2,50\end{array}$ & $\begin{array}{l}z=1,5379 \\
p=0,1241\end{array}$ \\
\hline Wyładowanie & $\begin{array}{l}\text { Nie } \\
\text { Tak }\end{array}$ & $\begin{array}{l}1,21 \\
1,43\end{array}$ & $\begin{array}{l}0,73 \\
0,61\end{array}$ & $\begin{array}{l}0,00 \\
0,00\end{array}$ & $\begin{array}{l}0,50 \\
1,00\end{array}$ & $\begin{array}{l}1,25 \\
1,50\end{array}$ & $\begin{array}{l}1,50 \\
2,00\end{array}$ & $\begin{array}{l}2,50 \\
3,00\end{array}$ & $\begin{array}{l}z=1,7635 \\
p=0,0778\end{array}$ \\
\hline Zażywanie substancji psychoaktywnych & $\begin{array}{l}\text { Nie } \\
\text { Tak }\end{array}$ & $\begin{array}{l}0,30 \\
0,42\end{array}$ & $\begin{array}{l}0,58 \\
0,69\end{array}$ & $\begin{array}{l}0,00 \\
0,00\end{array}$ & $\begin{array}{l}0,00 \\
0,00\end{array}$ & $\begin{array}{l}0,00 \\
0,00\end{array}$ & $\begin{array}{l}0,50 \\
0,88\end{array}$ & $\begin{array}{l}3,00 \\
2,50\end{array}$ & $\begin{array}{l}Z=0,9988 \\
p=0,3179\end{array}$ \\
\hline Zaprzestanie działań & $\begin{array}{l}\text { Nie } \\
\text { Tak }\end{array}$ & $\begin{array}{l}0,82 \\
0,88\end{array}$ & $\begin{array}{l}0,71 \\
0,77\end{array}$ & $\begin{array}{l}0,00 \\
0,00\end{array}$ & $\begin{array}{l}0,00 \\
0,00\end{array}$ & $\begin{array}{l}0,50 \\
1,00\end{array}$ & $\begin{array}{l}1,00 \\
1,50\end{array}$ & $\begin{array}{l}3,00 \\
2,50\end{array}$ & $\begin{array}{l}Z=0,4053 \\
p=0,6853\end{array}$ \\
\hline Obwinianie siebie & $\begin{array}{l}\text { Nie } \\
\text { Tak }\end{array}$ & $\begin{array}{l}0,96 \\
1,03\end{array}$ & $\begin{array}{l}0,75 \\
0,79\end{array}$ & $\begin{array}{l}0,00 \\
0,00\end{array}$ & $\begin{array}{l}0,50 \\
0,50\end{array}$ & $\begin{array}{l}1,00 \\
1,00\end{array}$ & $\begin{array}{l}1,50 \\
1,88\end{array}$ & $\begin{array}{l}3,00 \\
2,50\end{array}$ & $\begin{array}{l}Z=0,3410 \\
p=0,7331\end{array}$ \\
\hline
\end{tabular}


W niniejszym opracowaniu dokonano także porównania wyboru strategii radzenia sobie ze stresem u personelu pielęgniarskiego ze względu na badaną placówkę leczniczą. W wyniku analizy statystycznej stwierdzono, że personel pielęgniarski z Brodnicy istotnie częściej stosował strategię „pozytywne przewartościowanie" $(p<0,01)$. Pra- cownicy ochrony zdrowia z Rypina istotnie częściej wybierali strategię „poczucie humoru” $(p<0,05)$. Pielęgniarki/ arze i położne z Bydgoszczy istotnie częściej skłaniali się do wyboru strategii „poszukiwanie wsparcia emocjonalnego" $(p<0,05)$. Dane z obserwacji zawarto $w$ tabeli 10

Tabela 10. Strategie radzenia sobie ze stresem wg Mini-COPE ze względu na placówkę leczniczą

\begin{tabular}{|c|c|c|c|c|c|c|c|c|c|c|c|c|c|}
\hline $\begin{array}{c}\text { Strategie radzenia sobie } \\
\text { ze stresem } \\
\text { wg Mini-COPE }\end{array}$ & 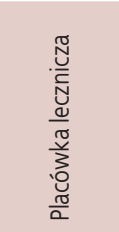 & 离 & ㅇ & $\stackrel{\check{\Sigma}}{\sum}$ & 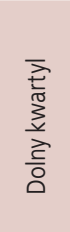 & 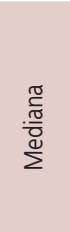 & 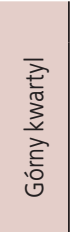 & $\begin{array}{l}\frac{E}{5} \\
\frac{\text { हn }}{\sqrt{n}} \\
\frac{\sqrt{0}}{\Sigma}\end{array}$ & 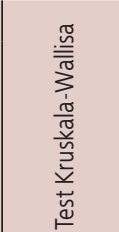 & $\begin{array}{l}\text { 을 } \\
\frac{\text { 은 }}{\oplus}\end{array}$ & $\begin{array}{l}\text { N } \\
\text { Ò } \\
\text { कo } \\
\text { ồ }\end{array}$ & Bonferro & $\stackrel{\frac{c}{0}}{\stackrel{x}{x}}$ \\
\hline $\begin{array}{l}\text { Aktywne radzenie } \\
\text { sobie }\end{array}$ & $\begin{array}{l}\text { Brodnica } \\
\text { Bydgoszcz } \\
\text { *NML } \\
\text { Rypin }\end{array}$ & $\begin{array}{l}2,16 \\
2,25 \\
2,14 \\
2,21\end{array}$ & $\begin{array}{l}0,67 \\
0,58 \\
0,67 \\
0,63\end{array}$ & $\begin{array}{l}0,50 \\
1,00 \\
0,00 \\
0,50\end{array}$ & $\begin{array}{l}2,00 \\
2,00 \\
2,00 \\
2,00\end{array}$ & $\begin{array}{l}2,00 \\
2,00 \\
2,00 \\
2,00\end{array}$ & $\begin{array}{l}2,50 \\
2,63 \\
2,50 \\
2,63\end{array}$ & $\begin{array}{l}3,00 \\
3,00 \\
3,00 \\
3,00\end{array}$ & $\begin{array}{l}H=0,4956 \\
p=0,9199\end{array}$ & $\begin{array}{l}1 \\
1 \\
1\end{array}$ & $\begin{array}{l}1 \\
1 \\
1\end{array}$ & $\begin{array}{l}1 \\
1 \\
1\end{array}$ & $\begin{array}{l}1 \\
1 \\
1\end{array}$ \\
\hline Planowanie & $\begin{array}{c}\text { Brodnica } \\
\text { Bydgoszcz } \\
\text { NML } \\
\text { Rypin }\end{array}$ & $\begin{array}{l}2,23 \\
2,19 \\
2,12 \\
2,11\end{array}$ & $\begin{array}{l}0,65 \\
0,55 \\
0,68 \\
0,73\end{array}$ & $\begin{array}{l}1,00 \\
1,00 \\
0,00 \\
0,00\end{array}$ & $\begin{array}{l}2,00 \\
2,00 \\
2,00 \\
1,50\end{array}$ & $\begin{array}{l}2,00 \\
2,00 \\
2,00 \\
2,00\end{array}$ & $\begin{array}{l}3,00 \\
2,50 \\
2,50 \\
3,00\end{array}$ & $\begin{array}{l}3,00 \\
3,00 \\
3,00 \\
3,00\end{array}$ & $\begin{array}{l}H=0,8124 \\
p=0,8465\end{array}$ & $\begin{array}{l}1 \\
1 \\
1\end{array}$ & $\begin{array}{l}1 \\
1 \\
1\end{array}$ & $\begin{array}{l}1 \\
1 \\
1\end{array}$ & $\begin{array}{l}1 \\
1 \\
1\end{array}$ \\
\hline $\begin{array}{l}\text { Pozytywne } \\
\text { przewartościowanie }\end{array}$ & $\begin{array}{c}\text { Brodnica } \\
\text { Bydgoszcz } \\
\text { NML } \\
\text { Rypin }\end{array}$ & $\begin{array}{l}2,04 \\
1,70 \\
1,56 \\
1,96\end{array}$ & $\begin{array}{l}0,62 \\
0,66 \\
0,76 \\
0,64\end{array}$ & $\begin{array}{l}1,00 \\
0,50 \\
0,00 \\
0,00\end{array}$ & $\begin{array}{l}1,50 \\
1,00 \\
1,00 \\
1,50\end{array}$ & $\begin{array}{l}2,00 \\
1,75 \\
1,50 \\
2,00\end{array}$ & $\begin{array}{l}2,50 \\
2,00 \\
2,00 \\
2,50\end{array}$ & $\begin{array}{l}3,00 \\
3,00 \\
3,00 \\
3,00\end{array}$ & $\begin{array}{l}H=11,922 \\
p=0,0077\end{array}$ & $\begin{array}{c}0,2546 \\
0,0416 \\
1\end{array}$ & $\begin{array}{c}0,2546 \\
1 \\
0,2637\end{array}$ & $\begin{array}{c}0,0416 \\
1 \\
0,0319\end{array}$ & $\begin{array}{c}1 \\
0,2637 \\
0,0319\end{array}$ \\
\hline Akceptacja & $\begin{array}{c}\text { Brodnica } \\
\text { Bydgoszcz } \\
\text { NML } \\
\text { Rypin }\end{array}$ & $\begin{array}{l}1,73 \\
1,88 \\
1,74 \\
1,82\end{array}$ & $\begin{array}{l}0,74 \\
0,71 \\
0,75 \\
0,69\end{array}$ & $\begin{array}{l}0,00 \\
0,00 \\
0,50 \\
0,00\end{array}$ & $\begin{array}{l}1,00 \\
1,50 \\
1,00 \\
1,50\end{array}$ & $\begin{array}{l}2,00 \\
2,00 \\
2,00 \\
2,00\end{array}$ & $\begin{array}{l}2,13 \\
2,50 \\
2,50 \\
2,13\end{array}$ & $\begin{array}{l}3,00 \\
3,00 \\
3,00 \\
3,00\end{array}$ & $\begin{array}{l}H=1,3666 \\
p=0,7134\end{array}$ & $\begin{array}{l}1 \\
1 \\
1\end{array}$ & $\begin{array}{l}1 \\
1 \\
1\end{array}$ & $\begin{array}{l}1 \\
1 \\
1\end{array}$ & $\begin{array}{l}1 \\
1 \\
1\end{array}$ \\
\hline Poczucie humoru & $\begin{array}{c}\text { Brodnica } \\
\text { Bydgoszcz } \\
\text { NML } \\
\text { Rypin }\end{array}$ & $\begin{array}{l}0,57 \\
0,60 \\
0,55 \\
0,89\end{array}$ & $\begin{array}{l}0,60 \\
0,61 \\
0,59 \\
0,72\end{array}$ & $\begin{array}{l}0,00 \\
0,00 \\
0,00 \\
0,00\end{array}$ & $\begin{array}{l}0,00 \\
0,00 \\
0,00 \\
0,50\end{array}$ & $\begin{array}{l}0,50 \\
0,50 \\
0,50 \\
1,00\end{array}$ & $\begin{array}{l}1,00 \\
1,00 \\
1,00 \\
1,13\end{array}$ & $\begin{array}{l}2,00 \\
2,50 \\
2,00 \\
3,00\end{array}$ & $\begin{array}{l}H=8,1737 \\
p=0,0426\end{array}$ & $\begin{array}{c}1 \\
1 \\
0,2641\end{array}$ & $\begin{array}{c}1 \\
1 \\
0,1597\end{array}$ & $\begin{array}{c}1 \\
1 \\
0,0828\end{array}$ & $\begin{array}{l}0,2641 \\
0,1597 \\
0,0828\end{array}$ \\
\hline Zwrot ku religii & $\begin{array}{c}\text { Brodnica } \\
\text { Bydgoszcz } \\
\text { NML } \\
\text { Rypin }\end{array}$ & $\begin{array}{l}1,46 \\
1,14 \\
1,29 \\
1,40\end{array}$ & $\begin{array}{l}1,00 \\
1,00 \\
1,01 \\
0,97\end{array}$ & $\begin{array}{l}0,00 \\
0,00 \\
0,00 \\
0,00\end{array}$ & $\begin{array}{l}1,00 \\
0,00 \\
0,50 \\
0,50\end{array}$ & $\begin{array}{l}1,50 \\
1,00 \\
1,00 \\
1,50\end{array}$ & $\begin{array}{l}2,00 \\
2,00 \\
1,88 \\
2,00\end{array}$ & $\begin{array}{l}3,00 \\
3,00 \\
3,00 \\
3,00\end{array}$ & $\begin{array}{l}H=2,8796 \\
p=0,4106\end{array}$ & $\begin{array}{c}0,9729 \\
1 \\
1\end{array}$ & $\begin{array}{c}0,9729 \\
1 \\
0,947\end{array}$ & $\begin{array}{l}1 \\
1 \\
1\end{array}$ & $\begin{array}{c}1 \\
0,947 \\
1\end{array}$ \\
\hline $\begin{array}{l}\text { Poszukiwanie wsparcia } \\
\text { emocjonalnego }\end{array}$ & $\begin{array}{c}\text { Brodnica } \\
\text { Bydgoszcz } \\
\text { NML } \\
\text { Rypin }\end{array}$ & $\begin{array}{l}2,02 \\
2,07 \\
1,70 \\
1,84\end{array}$ & $\begin{array}{l}0,71 \\
0,57 \\
0,65 \\
0,70\end{array}$ & $\begin{array}{l}0,50 \\
0,50 \\
0,50 \\
0,00\end{array}$ & $\begin{array}{l}1,50 \\
2,00 \\
1,13 \\
1,50\end{array}$ & $\begin{array}{l}2,00 \\
2,00 \\
1,75 \\
2,00\end{array}$ & $\begin{array}{l}2,50 \\
2,50 \\
2,00 \\
2,00\end{array}$ & $\begin{array}{l}3,00 \\
3,00 \\
3,00 \\
3,00\end{array}$ & $\begin{array}{l}H=9,7329 \\
p=0,0210\end{array}$ & $\begin{array}{c}1 \\
0,2874 \\
1\end{array}$ & $\begin{array}{c}1 \\
0,0216 \\
0,3074\end{array}$ & $\begin{array}{c}0,2874 \\
0,0216 \\
1\end{array}$ & $\begin{array}{c}1 \\
0,3074 \\
1\end{array}$ \\
\hline $\begin{array}{l}\text { Poszukiwanie wsparcia } \\
\text { instrumentalnego }\end{array}$ & $\begin{array}{l}\text { Brodnica } \\
\text { Bydgoszcz }\end{array}$ & $\begin{array}{l}1,93 \\
2,02\end{array}$ & $\begin{array}{l}0,66 \\
0,66\end{array}$ & $\begin{array}{l}1,00 \\
0,50\end{array}$ & $\begin{array}{l}1,50 \\
1,50\end{array}$ & $\begin{array}{l}2,00 \\
2,00\end{array}$ & $\begin{array}{l}2,13 \\
2,50\end{array}$ & $\begin{array}{l}3,00 \\
3,00\end{array}$ & $\begin{array}{l}H=6,927 \\
p=0,0743\end{array}$ & 1 & 1 & $\begin{array}{l}0,9364 \\
0,0566\end{array}$ & $\begin{array}{c}1 \\
0,8245\end{array}$ \\
\hline $\begin{array}{l}\text { Zajmowanie się } \\
\text { czymś innym }\end{array}$ & $\begin{array}{c}\text { NML } \\
\text { Rypin } \\
\text { Brodnica } \\
\text { Bydgoszcz } \\
\text { NML } \\
\text { Rypin }\end{array}$ & $\begin{array}{l}1,69 \\
1,82 \\
1,71 \\
1,88 \\
1,69 \\
2,02\end{array}$ & $\begin{array}{l}0,63 \\
0,68 \\
0,75 \\
0,60 \\
0,72 \\
0,75\end{array}$ & $\begin{array}{l}0,00 \\
0,00 \\
0,00 \\
0,50 \\
0,00 \\
0,00\end{array}$ & $\begin{array}{l}1,50 \\
1,50 \\
1,38 \\
1,50 \\
1,13 \\
1,50\end{array}$ & $\begin{array}{l}1,50 \\
2,00 \\
1,50 \\
2,00 \\
1,75 \\
2,00\end{array}$ & $\begin{array}{l}2,00 \\
2,00 \\
2,13 \\
2,00 \\
2,00 \\
2,50\end{array}$ & $\begin{array}{l}3,00 \\
3,00 \\
3,00 \\
3,00 \\
3,00 \\
3,00\end{array}$ & $\begin{array}{l}H=6,2958 \\
p=0,0981\end{array}$ & $\begin{array}{c}0,9364 \\
1 \\
1 \\
1 \\
0,2977\end{array}$ & $\begin{array}{c}0,0566 \\
0,8245 \\
1 \\
1 \\
1\end{array}$ & $\begin{array}{c}1 \\
1 \\
1 \\
0,1767\end{array}$ & $\begin{array}{c}1 \\
0,2977 \\
1 \\
0,1767\end{array}$ \\
\hline Zaprzeczanie & $\begin{array}{l}\text { Brodnica } \\
\text { Bydgoszcz } \\
\text { NML } \\
\text { Rypin }\end{array}$ & $\begin{array}{l}0,71 \\
0,89 \\
0,73 \\
0,97\end{array}$ & $\begin{array}{l}0,62 \\
0,75 \\
0,69 \\
0,78\end{array}$ & $\begin{array}{l}0,00 \\
0,00 \\
0,00 \\
0,00\end{array}$ & $\begin{array}{l}0,38 \\
0,50 \\
0,00 \\
0,50\end{array}$ & $\begin{array}{l}0,50 \\
1,00 \\
0,50 \\
1,00\end{array}$ & $\begin{array}{l}1,00 \\
1,50 \\
1,00 \\
1,63\end{array}$ & $\begin{array}{l}2,00 \\
3,00 \\
2,50 \\
2,50\end{array}$ & $\begin{array}{l}H=3,3377 \\
p=0,3424\end{array}$ & $\begin{array}{l}1 \\
1 \\
1\end{array}$ & $\begin{array}{l}1 \\
1 \\
1\end{array}$ & $\begin{array}{c}1 \\
1 \\
0,6885\end{array}$ & $\begin{array}{c}1 \\
1 \\
0,6885\end{array}$ \\
\hline Wyładowanie & $\begin{array}{c}\text { Brodnica } \\
\text { Bydgoszcz } \\
\text { NML } \\
\text { Rypin }\end{array}$ & $\begin{array}{l}1,14 \\
1,36 \\
1,14 \\
1,31\end{array}$ & $\begin{array}{l}0,64 \\
0,70 \\
0,82 \\
0,67\end{array}$ & $\begin{array}{l}0,00 \\
0,00 \\
0,00 \\
0,00\end{array}$ & $\begin{array}{l}0,50 \\
1,00 \\
0,50 \\
1,00\end{array}$ & $\begin{array}{l}1,00 \\
1,50 \\
1,00 \\
1,50\end{array}$ & $\begin{array}{l}1,50 \\
2,00 \\
1,50 \\
1,50\end{array}$ & $\begin{array}{l}2,50 \\
2,50 \\
3,00 \\
2,50\end{array}$ & $\begin{array}{l}H=4,0787 \\
p=0,2531\end{array}$ & $\begin{array}{c}0,9764 \\
1 \\
1\end{array}$ & $\begin{array}{l}0,9764 \\
0,5386 \\
1\end{array}$ & $\begin{array}{c}1 \\
0,5386 \\
1\end{array}$ & $\begin{array}{l}1 \\
1 \\
1\end{array}$ \\
\hline $\begin{array}{l}\text { Zażywanie } \\
\text { substancji } \\
\text { psychoaktywnych }\end{array}$ & $\begin{array}{l}\text { Brodnica } \\
\text { Bydgoszcz } \\
\text { NML } \\
\text { Rypin }\end{array}$ & $\begin{array}{l}0,27 \\
0,40 \\
0,40 \\
0,22\end{array}$ & $\begin{array}{l}0,59 \\
0,68 \\
0,66 \\
0,47\end{array}$ & $\begin{array}{l}0,00 \\
0,00 \\
0,00 \\
0,00\end{array}$ & $\begin{array}{l}1,00 \\
0,00 \\
0,00 \\
0,00\end{array}$ & $\begin{array}{l}0,00 \\
0,00 \\
0,00 \\
0,00\end{array}$ & $\begin{array}{l}0,00 \\
1,00 \\
0,50 \\
0,00\end{array}$ & $\begin{array}{l}2,50 \\
3,00 \\
2,50 \\
1,50\end{array}$ & $\begin{array}{l}H=3,4786 \\
p=0,3236\end{array}$ & $\begin{array}{l}1 \\
1 \\
1\end{array}$ & $\begin{array}{c}1 \\
1 \\
0,999\end{array}$ & $\begin{array}{c}1 \\
1 \\
0,7964\end{array}$ & $\begin{array}{c}1 \\
0,999 \\
0,7964\end{array}$ \\
\hline Zaprzestanie działań & $\begin{array}{c}\text { Brodnica } \\
\text { Bydgoszcz } \\
\text { NML } \\
\text { Rypin }\end{array}$ & $\begin{array}{l}0,86 \\
0,79 \\
0,75 \\
0,93\end{array}$ & $\begin{array}{l}0,52 \\
0,74 \\
0,76 \\
0,79\end{array}$ & $\begin{array}{l}0,00 \\
0,00 \\
0,00 \\
0,00\end{array}$ & $\begin{array}{l}0,50 \\
0,00 \\
0,00 \\
0,00\end{array}$ & $\begin{array}{l}1,00 \\
0,50 \\
0,50 \\
1,00\end{array}$ & $\begin{array}{l}1,13 \\
1,00 \\
1,00 \\
1,50\end{array}$ & $\begin{array}{l}2,00 \\
2,50 \\
3,00 \\
2,50\end{array}$ & $\begin{array}{l}H=2,3972 \\
p=0,4942\end{array}$ & $\begin{array}{l}1 \\
1 \\
1\end{array}$ & $\begin{array}{l}1 \\
1 \\
1\end{array}$ & $\begin{array}{l}1 \\
1 \\
1\end{array}$ & 1 \\
\hline Obwinianie siebie & $\begin{array}{c}\text { Brodnica } \\
\text { BydgoszCZ } \\
\text { NML } \\
\text { Rypin }\end{array}$ & $\begin{array}{l}1,13 \\
0,96 \\
0,93 \\
0,93\end{array}$ & $\begin{array}{l}0,75 \\
0,77 \\
0,72 \\
0,77\end{array}$ & $\begin{array}{l}0,00 \\
0,00 \\
0,00 \\
0,00\end{array}$ & $\begin{array}{l}0,50 \\
0,38 \\
0,50 \\
0,00\end{array}$ & $\begin{array}{l}1,00 \\
1,00 \\
1,00 \\
1,00\end{array}$ & $\begin{array}{l}1,50 \\
1,50 \\
1,00 \\
1,50\end{array}$ & $\begin{array}{l}3,00 \\
3,00 \\
3,00 \\
3,00\end{array}$ & $\begin{array}{l}H=1,3326 \\
p=0,7214\end{array}$ & $\begin{array}{l}1 \\
1 \\
1\end{array}$ & $\begin{array}{l}1 \\
1 \\
1\end{array}$ & $\begin{array}{l}1 \\
1 \\
1\end{array}$ & $\begin{array}{l}1 \\
1 \\
1\end{array}$ \\
\hline
\end{tabular}




\section{Dyskusja}

Stres jest czynnikiem, który zakłóca równowagę organizmu i wpływa pośrednio na zdrowie i chorobę jednostki. Definiowany jako obciążenie, presja czy napięcie. Przedłużające się sytuacje stresowe mogą potencjalnie powodować stany lękowe, nerwice, zachowania agresywne oraz szereg objawów fizjologicznych. Od predyspozycji jednostki zależy, czy stres wpływa korzystnie, mobilizująco (eustres) bądź negatywnie, w sposób szkodliwy (distres) [9]. W literaturze przedmiotu funkcjonują pojęcia procesu, strategii oraz stylu radzenia sobie ze stresem. Proces radzenia sobie ze stresem jest definiowany jako wiele zmieniających się z biegiem czasu strategii, wynikających zwłaszcza z charakteru konkretnej sytuacji oraz stanu psychofizycznego jednostki. Style radzenia sobie to charakterystyczne, typowe dla danej jednostki sposoby radzenia sobie w trudnych, stresujących sytuacjach. W myśl teorii Endlera i Parkera wyróżnia się: styl skoncentrowany na zadaniu, styl skoncentrowany na emocjach i styl skoncentrowany na unikaniu [10].

Nasze badanie pokazuje, że personel pielęgniarski najczęściej stosował strategie aktywnego radzenia sobie ze stresem: "aktywne radzenie sobie" i "planowanie". Przejawianie stylu skoncentrowanego na zadaniu to podejmowanie przez pielęgniarki i położne w obliczu stresu wysiłku, by rozwiązać problem. Strategia bezradności - "zażywanie substancji psychoaktywnych" - uzyskała najniższą średnią arytmetyczną według skali Mini-COPE w badanej próbie. Stosowanie strategii negatywnych pokazuje wśród pielęgniarek i położnych postawę bierną i unikową w stosunku do zaistniałego problemu. Jak wskazali Folkman i Lazarus, radzenie sobie ze stresem może wiązać się z podejmowaniem zachowań antyzdrowotnych [9]. W materiale własnym nie wykazano, aby stosowane strategie radzenia sobie ze stresem różniły się istotnie w grupie pielęgniarek i położnych. Otrzymane wyniki badania korespondują z wynikami przedstawionymi przez innych autorów. Basińska i Dziewiątkowska [11] dokonały oceny strategii radzenia sobie ze stresem wśród lekarzy chirurgów. Badani chirurdzy najczęściej stosowali w pracy strategie pozytywne: „bezpośredniego działania” $i$ „myślenia pozytywnego", a najmniej stosowali strategię „używanie alkoholu" jako sposobu na rozwiązanie sytuacji trudnych w pracy. Wykazano brak różnic istotnych statystycznie w częstości stosowania poszczególnych strategii pomiędzy chirurgami zatrudnionymi w szpitalach o różnym stopniu referencyjności. Wykazano ponadto, że im starsze były badane osoby, z dłuższym stażem pracy i w związku małżeńskim, tym bardziej skłonne były do stosowania strategii „unikanie/rezygnacja” w sytuacjach stresowych w pracy. Rezultaty badania własnego wykazały, że wraz ze wzro- stem wieku (powyżej50 lat) pielęgniarkii położne stosowały strategię negatywną „obwinianie siebie”. Wraz ze wzrostem stażu pracy (16-20 lat) personel pielęgniarski istotnie częściej wybierał style radzenia: „poszukiwanie wsparcia emocjonalnego" oraz "obwinianie siebie”. Doświadczenia życiowe są czynnikami modyfikującymi funkcjonowanie jednostki. Osoby, które stosują strategie negatywne, próbują trzymać się jak najdalej od sytuacji stresowych lub akceptować takie sytuacje, ponieważ są przekonane, że nie mają na nie żadnego wpływu [11]. Ponad połowa pielęgniarek oddziałów pediatrycznych w badaniu Stępień i Szmigiel [6] zadeklarowała, że radzi sobie ze stresem w związku z wykonywaną pracą. W walce ze stresem osoby te starają się myśleć pozytywnie, rozmawiać z bliskimi, słuchać muzyki oraz uprawiać sport. Respondenci do walk ze stresem wykorzystują poza konstruktywnymi metodami radzenia sobie ze stresem również te mniej konstruktywne: używanie niecenzuralnych słów, spożywanie zbyt dużych ilości pokarmów oraz stosowanie używek. Osoby z wyższym wykształceniem radzą sobie ze stresem zdecydowanie lepiej niż osoby z wykształceniem średnim. Nie stwierdzono zależności między wiekiem pielęgniarek a umiejętnością radzenia sobie ze stresem. Wraz z wydłużaniem się okresu zatrudnienia w oddziale pediatrycznym zmniejszeniu uległ odsetek respondentów deklarujących umiejętność radzenia sobie ze stresem związanym z wykonywaną pracą. Kupcewicz [12] dokonała analizy strategii radzenia sobie ze stresem u pielęgniarek anestezjologicznych w sytuacjach trudnych, czasami krytycznych, związanych ze specyfiką ich pracy. Wykazano, że najczęściej wybierane przez pielęgniarki są strategie, tworzące grupę strategii związanych z tzW. aktywnym radzeniem sobie.

Najczęściej stosowaną strategią była strategia aktywne radzenie sobie, na drugim planowanie, a następnie pozytywne przewartościowanie i akceptacja. Dalsze pozycje zajmowały strategie: poszukiwanie wsparcia emocjonalnego, poszukiwanie wsparcia instrumentalnego i "zachowania unikowe” - zajmowanie się czymś innym i wyładowanie. Udział pozostałych strategii był znacznie mniejszy, najniższe wyniki otrzymały dwie strategie: zaprzestanie działań i zażywanie substancji psychoaktywnych, które są wyrazem bezradności w grupie pielęgniarek.

Używanie tych substancji zaliczane jest do strategii ucieczkowo-unikowych. Środki odurzające (alkohol, leki uspokajające i przeciwbólowe, narkotyki) znoszą racjonalny ogląd rzeczywistości. Swoje działanie antystresowe wypełniają poprzez działanie uspokajające, zanik zmęczenia czy otwartość w kontaktach towarzyskich. Zanika zaś osobista gotowość do angażowania się $w$ inne sposoby zaradcze. Stąd przyjęte zostało określenie autode- 
struktywnych strategii radzenia sobie [9]. Nowakowska i wsp. [13] dokonali porównania radzenia sobie ze stresem wśród studentów zaocznych medycyny ratunkowej (niepracujących $w$ zawodzie) oraz studentów-ratowników medycznych, którzy pracują zawodowo. Autorzy wykazali, że studenci ratownictwa medycznego, którzy nie pracują w tym zawodzie, częściej stosują styl radzenia sobie ze stresem skoncentrowany na emocjach. Wykazują też tendencję do stosowania stylu skoncentrowanego na unikaniu problemu zasadniczego przez poszukiwanie innych celów zastępczych (głównie obniżanie napięcia poprzez poszukiwanie kontaktów towarzyskich). Badanie pokazuje również, że im starsi ratownicy medyczni, tym rzadziej stosowali strategie radzenia sobie ze stresem skoncentrowane na emocjach i na unikaniu problemu. Im dłużej badane osoby pracowały w zawodzie ratownika medycznego, tym częściej w sytuacjach stresowych stosowały styl radzenia sobie ze stresem skoncentrowany na zadaniu. Ponadto im dłuższy był staż pracy badanych ratowników, tym rzadziej korzystali oni ze stylu radzenia sobie ze stresem skoncentrowanym na unikaniu problemu, nie angażowali się w czynności zastępcze, nie poszukiwali kontaktów towarzyskich, które mogłyby obniżyć odczuwane napięcie.

Zawód położnej obecnie zyskał nowy wymiar i rangę. Położna jest samodzielnym pracownikiem, obarczonym ogromną odpowiedzialnością. Jej rola zawodowa polega na pełnieniu różnorakich funkcji, wymagających specyficznych predyspozycji oraz kwalifikacji. Analizy strategii radzenia sobie ze stresem u położnych dokonały Gruszczyńska i wsp. [14]. Badana próba charakteryzowała się przeciętnym poziomem odczuwanego stresu. Nie potwierdzono związku pomiędzy stażem pracy a poziomem stresu. W grupie położnych, najczęściej wybieranymi strategiami radzenia sobie ze stresem były: aktywne radzenie sobie, planowanie oraz poszukiwanie wsparcia emocjonalnego. Istotnie mniej pielęgniarki stosowały strategię bezradności i zachowania unikowe: sięganie po alkohol lub inne środki psychoaktywne, zaprzeczanie oraz zaprzestanie działań. Wykazano istotną statystycznie zależność między stażem pracy a strategią radzenia sobie ze stresem poprzez humor i żart. Im młodsze położne, tym częściej stosowały tę strategię. Powyższa strategia traktowana jest przez autorów inwentarza COPE, jako sposób łagodzenia przykrych emocji. Zawody medyczne są zaliczane do zawodów służb społecznych i należą do najsilniej stresujących [5]. Badanie przeprowadzone w Wielkiej Brytanii na próbie 17 tys. osób wykazało, że jeden z największych odsetków osób doświadczających wysokiego poziomu stresu występuje w zawodzie pielęgniarki [12]. W badaniu Perek i wsp.[15] wiek pielęgniarek miał istotny wpływ na styl radzenia sobie ze stresem - emocjonalny i unikowy (im młodsza badana osoba, tym silniejszy styl skoncentrowany na poszukiwaniu kontaktów towarzyskich). Staż pracy zaś istotnie wpływał na styl emocjonalny (im dłuższy staż pracy, tym słabszy styl emocjonalny).

Twórczy wkład w pracę powoduje także zmianę jej charakteru, a to z kolei stwarza potrzebę podnoszenia kwalifikacji i umożliwia jej zaspokojenie, czyli oddziałuje na jakość życia człowieka [16]. Nasze badanie pokazuje, że personel pielęgniarski ze stopniem magistra istotnie częściej wybierał strategie radzenia sobie ze stresem „pozytywne przewartościowanie” oraz „zwrot ku religii”. Pracownicy ochrony zdrowia, którzy ukończyli liceum medyczne istotnie częściej stosowali strategię bezradności - „zaprzestanie działań”. Nie stwierdzono, aby wykształcenie badanej próby w istotny sposób wpłynęto na wybór innych strategii radzenia sobie ze stresem. W badaniu Grochowskiej i wsp. [17] akceptację, jako sposób radzenia sobie z sytuacjami trudnymi, częściej wybierały osoby z wykształceniem wyższym licencjackim, osoby, które ukończyły studium zawodowe lub liceum medyczne, rzadziej - legitymujące się wykształceniem wyższym magisterskim. Zwrot ku religii również wybierany był najczęściej przez pielęgniarki, które ukończyły studium zawodowe, liceum medyczne lub studia I stopnia, rzadziej przez pielęgniarki z wykształceniem magisterskim. Stwierdzono ponadto, że pielęgniarki, które ukończyły studium zawodowe, częściej niż pozostałe badane (z wykształceniem średnim, wyższym I stopnia lub wyższym II stopnia) w sytuacjach trudnych wybierały strategię unikową, opartą na zajmowaniu się czymś innym. Podobnie zaprzestanie działań (strategia bezradności), traktowane jako sposób radzenia sobie z trudnościami, charakterystyczne było dla pielęgniarek, które ukończyły studium zawodowe, rzadziej dla badanych z wykształceniem średnim, wyższym licencjackim lub wyższym magisterskim.

Umiejętność poprawnego i efektywnego komunikowania się jest podstawowym narzędziem umożliwiającym współpracę w zespole interdyscyplinarnym. Sprawny przepływ informacji zwiększa efektywność pracy oraz satysfakcję z jej wykonania. W opiece zdrowotnej nieodzowna jest wydajna praca zespołowa, która przyczynia się do zwiększenia poziomu satysfakcji zawodowej, będącej jednym z decydujących determinant zdrowego środowiska pracy [12]. Bardzo często w środowisku pracy trudne sytuacje mogą być spowodowane przez konflikty międzyludzkie, które występują zarówno w zespole terapeutycznym, jak i w kontaktach z rodziną chorego. Grochowska i wsp. [17] podają, że tylko 1\% respondentek deklarowała brak współpracy pomiędzy grupami zawodowymi i tyle samo badanych pielęgniarek wskazywało na niewystarczające 
wsparcie ze strony przełożonych. Perek i wsp. [15] donoszą, że spośród trudnych sytuacji wynikających z relacji interpersonalnych $w$ zespole terapeutycznym wskazało ponad $50 \%$ respondentów na brak współpracy. Na niewystarczające wsparcie ze strony przełożonych wskazało $77,8 \%$ ankietowanych z grupy II (OIT) oraz $50,0 \%$ z grupy I (SOR). W materiale własnym, brak wsparcia ze strony przełożonych zadeklarowało 21,84\% pracowników, natomiast brak współpracy między poszczególnymi członkami zespołu terapeutycznego stwierdziło $25,29 \%$ respondentów, a zjawiska mobbingu doświadczyło 17,24\% badanych. Jak donoszą Pietraszek i wsp. [18] jednymi z głównych "dużych" stresorów w miejscu pracy, w opinii pielęgniarek, były konflikty interpersonalne ze współpracownikami (37,05\%) i przełożonymi (34,89\%). Rezultaty naszego badania wskazują, że brak współpracy między poszczególnymi członkami zespołu terapeutycznego istotnie częściej warunkował wybór strategii radzenia sobie ze stresem "aktywne radzenia sobie” oraz "zajmowanie się czymś innym". Brak wsparcia ze strony przełożonych i nadmiar obowiązków nie miały związku z wyborem żadnego stylu radzenia sobie w sytuacjach trudnych $w$ badanej próbie. Ogińska i Żuralska [19] wskazały natomiast, że obciążenie stresem wśród pielęgniarek pracujących na oddziałach neurologicznych może wynikać między innymi z niewłaściwej atmosfery w pracy, relacji z przełożonymi oraz braku życzliwości między współpracownikami. Zdecydowana większość ankietowanych deklarowała, że brak szacunku dla pielęgniarek jest przyczyną nasilenia stresu w stopniu maksymalnym. W badaniu Pietraszek i wsp. [18] w przypadku „konfliktów i złego traktowania przez przełożonych" zmienną istotną statystycznie okazała się być zmienna demograficzna - miejsce zamieszkania. Był to czynnik o bardzo wysokim nasileniu wśród większego odsetka respondentów zamieszkujących duże miasta (37,14\%). Z kolei dla większości respondentów zamieszkujących małe miasta $(41,18 \%)$ i wsie $(34,96 \%)$ był to czynnik stresujący o wysokim nasileniu. Konflikty w miejscu pracy i złe relacje z lekarzami okazały się stresorem o bardzo wysokim nasileniu dla pielęgniarek z wyższym wykształceniem. Przez lata skutecznie panował pogląd o niższej randze zawodu pielęgniarki i położnej w stosunku do zawodu lekarza. W tym paternalistycznym modelu, gdzie opinia pielęgniarki, dotycząca zdrowia pacjenta i opiekowania się nim, nie jest brana pod uwagę, jest to problem dla pielęgniarki, zwłaszcza, gdy dostrzega ona możliwości pewnych zmian, udogodnień, których nie dostrzega lekarz. Dominacja zawodu lekarza nad zawodem pielęgniarki prowadzi do zagrożenia dla dobrej współpracy i komunikacji w zespole [20]. Pawełczak i Gaszyński [21] wyka- zali, że czynniki stresogenne związane ze środowiskiem pracy wśród pielęgniarek anestezjologicznych to: brak współpracy z personelem lekarskim, konflikty w zespole pielęgniarskim, niewystarczająca obsada, nadmiar pracy i obciążanie zadaniami. Stresogenne okazały się także takie czynniki, jak: brak poszanowania ze strony innych, brak wsparcia przełożonych, rywalizacja, konieczność ciągłego doszkalania się, niskie pobory, dyspozycyjność oraz niski prestiż wykonywanego zawodu oraz świadomość odpowiedzialności i ryzyka.

Aktywność zawodowa dorosłego człowieka jest bardzo ważna, nie tylko ze względu na jej materialny wymiar, ale także ze względu na kształtowanie się więzi społecznych. Wpływ pracy na nasze życie może być pozytywny, ale może rzutować też negatywnie na życie prywatne, może być również źródłem frustracji i dyskomfortu psychicznego. Zadowolenie z pracy pielęgniarek i położnych warunkuje jakość świadczonych usług, czyli jakość opiek medycznej. Poziom zadowolenia jest jednym z najistotniejszych mierników postaw pracownika wobec pracy. Stopień satysfakcji jest uzależniony od zaspokojenia potrzeb materialno-bytowych oraz potrzeb psychospołecznych człowieka (m.in. możliwość wykazania się swoimi zdolnościami i kwalifikacjami, przekonanie o wartości i użyteczności społecznej wykonywanej pracy). W badaniach europejskiego projektu NEXT przeprowadzonego wśród pielęgniarek dziesięciu krajów stwierdzono, że na skali zadowolenia z pracy, wśród polskich pielęgniarek uzyskano najniższe wyniki ze wszystkich badanych krajów [20] Ostrowicka i wsp. [22] wykazali, że personel pielęgniarski w zdecydowanej większości określa swoją pracę, jako satysfakcjonującą, bo aż 87\% respondentów, którzy pracowali w placówkach prywatnych i $74 \%$ badanych pracowników z placówek publicznych, jest zadowolonych ze swojej pracy. W materiale własnym wykazano, że prawie większość personelu pielęgniarskiego $(77,59 \%)$ była zadowolona z osiągnięć zawodowych. Ale $16,67 \%$ respondentów zadeklarowała występowanie problemów rodzinnych w związku z wykonywaną pracą. W innym badaniu ponad połowa badanych pielęgniarek była zadowolona ze swojej pracy (zadowolona 39\%, bardzo zadowolona $16 \%)$. Jedynie $4 \%$ badanych była bardzo niezadowolona [20]. Badanie nasze dowodzi, że ponad połowa $(59,19 \%)$ respondentów stwierdziła, że chęć niesienia pomocy potrzebującym skłoniła ich do wyboru zawodu. Przez przypadek wykonuje zawód medyczny aż 23,56\% pielęgniarek i położnych. Kociuba-Adamczuk [20] wykazała, że dominującym motywem wyboru zawodu pielęgniarki była chęć pomagania ludziom (51\%). Innym motywem wyboru zawodu zdaniem respondentek było zainteresowanie pro- 
blematyką medyczną (20,4\%), motywacja ze strony rodziny $(17,3 \%)$ oraz powołanie $(15,3 \%)$. Niestety pewna grupa pielęgniarek wybrała zawód przez przypadek (14,3\%). Kędra i Sanak [23] wykazały, że wśród czynników, które w dużym stopniu negatywnie oddziaływały na poczucie braku satysfakcji i zadowolenia z pracy były związane z warunkami płacowymi: poczucie nieadekwatności wynagrodzenia do wymagań, poczucie nieadekwatności wynagrodzenia do wkładu własnej pracy oraz nieakceptowana relacja zarobków w stosunku do innych grup zawodowych. Odmienne wnioski z badania wykazała Wzorek [24], gdyż badana próba pielęgniarek pracujących w oddziałach intensywnej terapii, neurologii oraz przychodniach na terenie województwa świętokrzyskiego, w nieznacznym odsetku mówiła o braku satysfakcji z wykonywanej pracy. Pielęgniarki najczęściej radziły sobie ze stresem poprzez szczerą rozmowę z bliską osobą, a także pozytywne myślenie. W innym doniesieniu udowodniono, że ponad połowa $(59,8 \%)$ pielęgniarek była bardzo niezadowolona ze swojego wynagrodzenia. Jeśli chodzi o płacę za weekendy i święta, tylko 4,7\% respondentów było bardzo zadowolonych z wynagrodzenia [25]. Poziom satysfakcji zawodowej był istotnym predyktorem wyboru strategii radzenia sobie ze stresem (w materiale własnym). Pielęgniarki i położne zadowolone z wykonywanej pracy istotnie częściej stosowały strategie: pozytywnego przewartościowania, zwrot ku religii, poszukiwanie wsparcia emocjonalnego i instrumentalnego.

Intensywne zaangażowanie jednostki w problemy innych osób powoduje silne napięcie nerwowe. Proces wypalenia zawodowego jest nieuchronną konsekwencją destrukcji, która zachodzi w psychice osób nadmiernie eksploatujących swoje siły i energię. Dotyczy to szczególnie przedstawicieli zawodów tzw. służb społecznych, głównie pielęgniarek i położnych [6]. W materiale własnym wykazano, że najczęściej odczuwanymi objawami dotyczącymi sfery psychicznej wśród badanej próby były: nerwowość $(56,90 \%)$, rozdrażnienie $(51,15 \%)$, zaburzenia snu $(36,78 \%)$, obniżony nastrój $(35,63 \%)$ oraz uczucie gniewu (33,91\%). Zmienna uczucie gniewu warunkowała wybór strategii bezradności (zażywanie substancji psychoaktywnych) i zachowań unikowych (wyładowanie). Uczucie bezradności/bezsilności było predyktorem stylów: pozytywne przewartościowanie i zażywanie substancji psychoaktywnych. Poszukiwanie wsparcia emocjonalnego dotyczyło istotnie częściej pielęgniarek i położnych, które deklarowały uczucie osłabienia/braku sił. W badaniu Stępień i Szmigiel [6] prawie jedna trzecia badanych pielęgniarek z oddziałów pediatrycznych wskazała na problemy zdrowotne i wybuchy agresji, a kolejne 19\% na nerwice i uczucie lęku jako najważniejsze skutki pracy w niekorzystnych warunkach. Ponad połowa ankietowanych (54\%) zadeklarowała, że stres przyczynił się do zaostrzenia dolegliwości bólowych głowy, u 46\% nasiliła się bezsenność, $16 \%$ zaobserwowało u siebie biegunki, 10\% - alergie, $9 \%$ - zaparcia, a 8\% - inne dolegliwości, takie jak: bóle brzucha, nadmierny apetyt, senność, bóle w klatce piersiowej, bóle żołądka oraz nerwobóle klatki piersiowej. W naszym badaniu personel pielęgniarski zgłaszał najczęściej symptomy stresu: bóle okolic kręgosłupa (64,37\%), długo utrzymujące się nadmierne napięcie emocjonalne $(40,23 \%)$, wzmożoną potliwość $(29,88 \%)$ oraz bóle i zawroty głowy $(25,29 \%)$. Rezultaty naszego badania dowiodły, że dolegliwości somatyczne warunkowały wybór strategii aktywne radzenie sobie (akceptacja, pozytywne przewartościowanie) i zachowania unikowe (zaprzeczanie). Uchmanowicz i wsp. [26] udowodnili, że stres w pracy pielęgniarek był skorelowany z brakiem zdolności do koncentracji uwagi, brakiem sił oraz energii do pracy, brakiem motywacji do dalszej pracy, zniechęceniem do jej dalszego wykonywania czy wreszcie odczuwanymi problemami ze snem. Kupcewicz [12] podaje, że poczucie jakości życia pielęgniarek anestezjologicznych $w$ domenie somatycznej było związane ze strategiami aktywne radzenie sobie i pozytywne przewartościowanie. Strategie wyrażające bezradność (zażywanie substancji psychoaktywnych i zaprzestanie działań) były ujemnie związane z jakością życia w wymiarze somatycznym. Odnosząc się do problemu radzenia sobie ze stresem $w$ pracy personelu pielęgniarskiego, należy wspomnieć o badaniach światowych na ten temat, które nie różnią się istotnie od doniesień polskich autorów. W badaniu Tesfaye [27] wykazano, że pielęgniarki z południowo-zachodniej Etiopii, które pracowały w szpitalu publicznym, stosowały najczęściej strategie radzenia sobie skoncentrowane na działaniu, planowaniu oraz wsparciu społecznym (między współpracownikami, osobami bliskimi). Istotnie mniej pielęgniarki stosowały strategie negatywne wyrażając złość na rodzinę i znajomych czy zażywając substancje psychoaktywne. W innym doniesieniu czytamy, że większość pielęgniarek stosowała adaptacyjne radzenie sobie, a kilka strategii związanych było ze stylem unikowym [28]. Strategie unikowe i reakcje depresyjne były częściej stosowane przez pielęgniarzy niż przez pielęgniarki w badaniu Yoshida i wsp. [29]. Doświadczanie stresów życiowych odgrywa znaczącą rolę w etiologii zaburzeń depresyjnych. Badania pokazują, że depresja kliniczna jest związana ze zmianami odporności na poziomie komórkowym, wzrostem ilości białych krwinek [9].

W trudnej opiece nad osobami chorymi na nowotwory istnieje potrzeba opracowania przez personel pielęgniar- 
ski strategii radzenia sobie ze stresem, z uwzględnieniem aspektów etycznych związanych z różnymi sytuacjami i relacjami w kontekście opieki, które można zdefiniować jako zestaw reakcji behawioralnych, sytuacji stresowej, modyfikacji otoczenia w celu jak najlepszego dopasowania się do zdarzenia stresora, w celu zmniejszenia lub zminimalizowania jego awersyjnego charakteru. W kontekście szpitalnym zespół pielęgniarski przyjmuje na siebie wielką odpowiedzialność w stosunku do tych pacjentów, posiadając kompetencje do pomocy w diagnostyce, leczeniu, rehabilitacji i opiece nad krewnymi. Autorzy niniejszego opracowania dokonali porównania stylów radzenia sobie ze stresem ze względu na różną specyfikę pracy pielęgniarek i położnych. Wykazano, że pracownicy Centrum Onkologii w Bydgoszczy istotnie częściej poszukiwali wsparcia społecznego w radzeniu sobie w sytuacjach trudnych związanych z wykonywaną pracą. Nie dziwi fakt, że personel poszukuje wsparcia emocjonalnego, gdyż musi trwale radzić sobie zsytuacjami cierpieniaiśmierci wśrodowisku pracy. Dla emocjonalnego stylu radzenia sobie, istotne było spostrzeganie sytuacji, jako zagrożenia. Determinantami strategii radzenia sobie ze stresem w pozostałych placówkach leczniczych, były strategie aktywne („pozytywne przewartościowanie”) oraz „poczucie humoru”, jako odrębny element stylu radzenia sobie. Według literatury przedmiotu nie dowiedziono jednoznacznej zdrowotnej przewagi któregoś ze stylów radzenia sobie w sytuacjach trudnych. Należy brać pod uwagę zarówno kontekst sytuacyjny, jak i kryterium ze względu, na które oceniana jest efektywność działań jednostki [9].

Zdrowie psychofizyczne personelu pielęgniarskiego odgrywa ważną rolę w zapewnianiu wysokiej jakości opieki zdrowotnej. Personel pielęgniarski w większości placówek medycznych jest najbardziej niedocenianym personelem, mimo że są to ludzie, którzy opiekują się naszymi bliskimi przez całą dobę.

\section{Wnioski}

Wyniki badania własnego potwierdziły założenie, że wykonywanie zawodu pielęgniarki/pielęgniarza i położnej w istotny sposób wiąże się ekspozycją na występowanie stresu. Pomimo licznych czynników, które wywołują wzmożone napięcie emocjonalne u personelu pielęgniarskiego, badana próba stosowała najczęściej aktywne strategie neutralizacji stresu, co w znaczny sposób przyczynia się do zachowania zdrowia psychosomatycznego.

\section{Oświadczenia}

Oświadczenie dotyczące konfliktu interesów

Autorzy deklarują brak konfliktu interesów.

Źródła finansowania

Autorzy deklarują brak źródeł finansowania.
Piśmiennictwo

1. Iwanowicz-Palus G, Kicia M. Uwarunkowania zespołu wypalenia zawodowego w pracy położnej. W: Makara-Studzińska M, Iwanowicz-Palus G. [red.]. Psychologia w położnictwie i ginekologii. Wydawnictwo Lekarskie PZWL, Warszawa 2009, s. 62-70.

2. Andruszkiewicz A. Typy zachowań w pracy i wpływ na zdrowie psychiczne pielęgniarek. Probl Pielęg. 2010; 18(2): 91-96.

3. Skorupka-Król A, Szabla A, Bodys-Cupak I. Opinie pielęgniarek na temat czynników stresogennych związanych z ich środowiskiem pracy. Pielęg XXI wieku. 2014; 1(46): 23-26.

4. Tartas M, Derewicz G, Walkiewicz M, Budziński W. Źródła stresu zawodowego $\mathrm{W}$ pracy pielęgniarek zatrudnionych w oddziałach o dużym obciążeniu fizycznym i psychicznym - hospicjum oraz chirurgii ogólnej. Ann. Acad. Med. Gedan. 2009; 39: 145-153

5. Ogińska-Bulik N. Stres zawodowy w zawodach usług społecznych. Wydawnictwo Difin, Warszawa 2006, s. 13-16.

6. Stępień M, Szmigiel M. Stres personelu pielęgniarskiego związany z pracą na oddziałach pediatrycznych. Piel Pol. 2017: 1(63): 62-68.

7. Dąbska O, Wołoszynek E, Kowalczyk A, Kozłowska E. Sposoby radzenia sobie ze stresem - badanie ankietowe studentów wybranych szkół wyższych z Lublina. Piel Zdr Publ. 2017; 26(1): 27-34

8. Juczyński Z, Ogińska-Bulik N. Narzędzia pomiaru stresu i radzenia sobie ze stresem. Pracownia Testów Psychologicznych Polskiego Towarzystwa Psychologicznego, Warszawa 2009.

9. Sygit-Kowalkowska E. Radzenie sobie ze stresem, jako zachowanie zdrowotne człowieka - perspektywa psychologiczna. Hygeia Public Health 2014; 49(2): 202-208.

10. Kopeć M, Terelak JF. Style poznawcze a style radzenia sobie ze stresem u osób z przewlekłym bólem kręgosłupa. Stud Psychol. 2009; 9: 57-74.

11. Basińska MA, Dziewiątkowska K. Strategie radzenia sobie ze stresem w pracy stosowane przez chirurgów zatrudnionych w różnych szpitalach - badanie pilotażowe. Pol Przegl Chir 2012; 84(2): 129-13

12. Kupcewicz E. Jakość życia pielęgniarek a strategie radzenie sobie ze stresem doświadczanym w środowisku pracy. Med Og Nauk Zdr. 2017; 23(1): 62-67.

13. Nowakowska K, Jabłkowska-Górecka K, Borkowska A. Style radzenia sobie ze stresem i zespół wypalenia zawodowego u studentów ratownictwa medycznego i ratowników medycznych. Psychiatr. Psychol. Klin. 2009; 9(4): 242-248.

14. Gruszczyńska M, Skowrońska E, Bator A, Bąk-Sosnowska M. Staż pracy, poziom wypalenia zawodowego i strategie radzenia sobie ze stresem wśród położnych. Med. Og Nauk Zdr. 2014; 20(3): 276-281.

15. Perek M, Kózka M, Twarduś K. Trudne sytuacje w pracy pielęgniarek pediatrycznych i sposoby radzenia sobie z nimi. Probl Piel. 2007; 15(4); 223-228.

16. Baraniak B. Metody badania pracy. Wydawnictwa Akademickie i Profesjonalne, Warszawa 2009, s. 43-44.

17. Grochowska A, Bodys-Cupak I, Korus M. Sposoby radzenia sobie z trudnościami przez pielęgniarki pracujące na oddziałach pediatrycznych. Piel Pol. 2017; 1(63): 97-104.

18. Pietraszek A, Charzyńska-Gula M, Łuczyk M, Szadowska -Szlachetka Z, Kachaniuk H, Kwiatkowska J. Analiza przyczyn stresu zawodowego w opinii pielęgniarek. J Educ Health Sport. 2016; 6(9): 643-652.

19. Ogińska J, Żuralska R. Wypalenie zawodowe wśród pielęgniarek pracujących na oddziałach neurologicznych. Probl Piel. 2010; 18(4): 435-442. 
20. Kociuba-Adamczuk K. Satysfakcja pielęgniarek/pielęgniarzy z pracy zawodowej. Profilaktyka iEdukacja Zdrowotna. http:// www.neurocentrum.pl/dcten/wp-content/uploads/kociuba-adamczuk k5p.pdf [dostęp: 26.11.18, godz.19:03]

21. Pawełczak E, Gaszyński T. Sytuacje stresogenne w zawodzie lekarza anestezjologa i pielęgniarki anestezjologicznej. Anest Ratow. 2013; 7: 19-26.

22. Ostrowicka M, Walewska-Zielecka B, Olejniczak D. Czynniki motywujące i satysfakcja z pracy pielęgniarek w wybranych placówkach publicznej i prywatnej służby zdrowia. Zdr Publ Zarz. 2013; 11(2): 191-209.

23. Kędra E, Sanak K. Stres i wypalenie zawodowe w pracy pielęgniarek. Piel. Zdr. Publ. 2013; 3(2): 119-132.

24. Wzorek A. Porównanie przyczyn stresu wśród pielęgniarek pracujących na oddziałach o różnej specyfice. Stud Med. 2008; 11: 33-37.

25. Semachew A, Belachew T, Tesfaye T, Adinew YM. Predictors of job satisfaction among nurses working in Ethiopian public hospitals, 2014: institution-based cross-sectional study. Hum Resour Health 2017; 15: 31 https://human-resources-health. biomedcentral.com/articles/10.1186/s12960-017-0204-5 [dostęp 2.12.18, godz.15:09].

26. Uchmanowicz I, Jankowska-Polańska B, Bronowicka G. Zjawisko wypalenia zawodowego wśród pielęgniarek pracujących na oddziałach onkologicznych - badanie wstępne. Probl Piel. 2013; 21(4): 476-783.
27. Tesfaye TD. Coping strategies among nurses in South-west Ethiopia: descriptive, institution-based cross-sectional study. BMC Res Notes. 2018;11:421. https://bmcresnotes.biomed central.com/articles/10.1186/s13104-018-3557-5 [dostęp 29.11.18, godz.20:21].

28. Sudhaker C, Gomes L. Stress, coping strategies and the job quality index of nurses working in selected multispecialty hospitals - towards human resource development. J Acad Hosp Adm. 2010; 22(1): 1-5.

29. Yoshida E, Yamada K, Marioka I. Sense of coherence (SOC) occupational stress reactions, and the relationship of $\mathrm{SOC}$ with occupational stress reactions among male nurses working. Sangyo Eiseigaku Zasshi. 2014; 56(5): 152-161.

Zaakceptowano do edycji: 15.12.2019 Zaakceptowano do publikacji: 15.02.2020

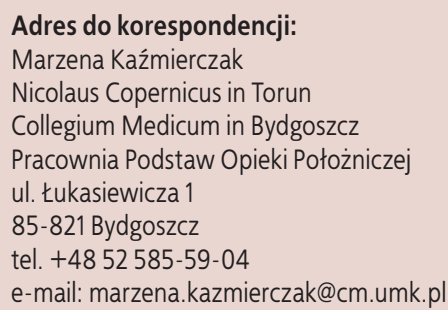

